\title{
Adaptive Reuse Decisions for Historic Buildings in Relation to Energy Efficiency and Thermal Comfort-Cairo Citadel, a Case Study from Egypt
}

\author{
Yasmine Sabry Hegazi ${ }^{1, *(\mathbb{D})}$, Heidi Ahmed Shalaby ${ }^{1,2}$ and Mady A. A. Mohamed ${ }^{1,3}$ (D) \\ 1 Department of Architecture, Zagazig University, Zagazig 44519, Egypt; heidi.shalaby@yahoo.com (H.A.S.); \\ momohamed@effatuniversity.edu.sa (M.A.A.M.) \\ 2 National Organization for Urban Harmony (NOUH), Cairo 11411, Egypt \\ 3 Architecture Department, College of Architecture and Design, Effat University, Jeddah 21478, Saudi Arabia \\ * Correspondence: yasmine_sabry@yahoo.com
}

check for updates

Citation: Hegazi, Y.S.; Shalaby, H.A.; Mohamed, M.A.A. Adaptive Reuse Decisions for Historic Buildings in Relation to Energy Efficiency and Thermal Comfort-Cairo Citadel, a Case Study from Egypt. Sustainability 2021, 13, 10531. https://doi.org/ $10.3390 /$ su131910531

Academic Editors: David Hou Chi Chow and Giacomo Salvadori

Received: 26 June 2021

Accepted: 14 September 2021

Published: 23 September 2021

Publisher's Note: MDPI stays neutral with regard to jurisdictional claims in published maps and institutional affiliations.

Copyright: (c) 2021 by the authors. Licensee MDPI, Basel, Switzerland. This article is an open access article distributed under the terms and conditions of the Creative Commons Attribution (CC BY) license (https:/ / creativecommons.org/licenses/by/ $4.0 /)$.

\begin{abstract}
Historic buildings still perform their role today by being utilized either for their original purpose or a new purpose for which they are adapted. These buildings have specific requirements that inhabitants must follow. These requirements and relating uses and maintenance procedures result from adaptive reuse decisions, which may not be the most optimal scenario. The imperative is that historic buildings are used in a manner that, on the one hand, does not endanger their value related to heritage and tradition, and on the other hand, guarantees a degree of utility for their inhabitants, such as acceptable performance with regards to either air cooling or heating. The challenge is how to optimize the use of energy for either air cooling or heating, provided that adaptive reuse decisions are grounded in certain very specific and very rigid principles. The latter render is extremely difficult to meet the twin challenges of ensuring energy efficiency and thermal comfort for inhabitants while at the same time complying with the adaptive reuse principles. To address this challenge and gain an insight into ways of navigating it, a Post Occupancy Evaluation (POE) is conducted in Former Soldier's Residence in the Cairo Citadel, Cairo, Egypt, which is now used as the National Organization for Urban Harmony's (NOUH) administrative head office, this research can be considered as a single domain from which many other possible multi-domains can be investigated while studying the case of adaptive reuse. Other aspects such as indoor environmental quality, air quality, acoustics and lighting might act as multiple approaches appear to be widely used according to this review study, and in the future, the authors intend to test this research with the current single approach used in this research, which is the thermal comfort. POE includes both objective and subjective assessment, the POE limitation at this research to those assessment while a multi-perceptional and behavioral factors might be used as physical, contextual, personal, and others. The simulation and the survey methods were employed consecutively to assess the case study. By considering the research results, it was determined that the building consumes unnecessary energy by its current use of air conditioning system.
\end{abstract}

Keywords: historic buildings; adaptive reuse; energy efficiency; thermal comfort; citadel; active heating

\section{Introduction}

Green, smart, and embracing the heritage: reconciling energy efficiency, utility, and preservation needs of historic buildings.

Adaptive reuse is considered one of the most common ways of preserving historic buildings and considers many aspects of using a building according to the chosen use. Buildings can be classified as reused, i.e., using the historic building for the same original use without modification. Simultaneously, adaptive reuse is performed by applying a new use for a building whose original usage has changed. This is the case for the chosen case study, as the army no longer uses the Citadel. This adaptation may need some modification 
to achieve the minimum level of adaptation for the new service. The adaptive reuse objective is to preserve the heritage and architectural values and to perform maintenance through continuous supervision of the building by its users. The economic aim is a vital aspect of closed monuments all over Egypt. Moreover, the government requires many usable buildings, driving the necessity for adaptive reuse principles. In its current role, the historic building keeps the community aware of its value. It helps with the preservation of history and the communication between people and this history [1].

Respecting the properties of every historic building, district, or city is an essential part that to fulfill the benefit from the community with full respect to the environmental context, as the operation of adaptive reuse cannot exclude the community, this adaptive thinking needs decision assistance in order to control the complex interventions related to adaptive reuse [2].

Suitability is an essential factor in adapting a historic building for reuse, and it should be visually suitable and reversible. Moreover, it must not be harmful to the building's structural performance due to any dead or live loads related to use. Economic efficiency ensures that the required maintenance of that use is not higher than the service. In the case study, the building was used as an administrative and cultural building without any significant modifications. Citadel buildings of the northern enclosure are used by Antiquities and Culture's ministries, such as the Historic Cairo administration, the National Organization of Urban Harmony, monument registration administration, tourism police, and small museums [3]. Investigations in historic buildings are very challenging, especially when the available resources are limited and priorities are interrelated, so the objective has to be well defined from the decision maker's point of view to respect the budget constraints which may or may not support investing in energy strategies for the historic buildings [4].

Another essential factor that limits adapting historic buildings and its subsequent visual impact is the energy consumption and thermal comfort of the occupants of historic buildings - which is the main focus of the current paper-due to a lack of foresight and because energy consumption strategies may conflict with the maintenance of the historic building (e.g., installing solar energy and adding insulation layers). Often, when adapting historic buildings for reuse, energy efficiency goes unconsidered, despite being quite straightforward. Sometimes, the historic building is affected visually as the cooling system's requirements in Egyptian historic buildings are often exposed. No internal hidden pipes are allowed to be implemented inside the historic walls according to the Egyptian law of antiquities-no.117, 1983, which was updated and developed in 2010 [5].

The historic building may use thick stone walls and multiple layers of flooring and ceilings crafted from wooden elements and other traditional insulation materials. This construction already keeps the heat out in summer more effectively than concrete buildings; using this method, energy consumption can be more easily achieved. However, it still needs to be demonstrated that there is no need for air conditioning in these kinds of historic buildings [6]. Historic buildings have many privileges in terms of sustainability. However, in some cases, reusing a building and its requirements of energy can make achieving sustainability seem to be a big challenge [7]. This research focuses on historic buildings constructed from the traditional materials at the arid zone of Egypt to investigate the adaptive reuse thinking, thermal comfort of their occupants, and energy consumption.

\section{Theories of Adaptive Reuse-Literature Perspective}

Adapting heritage buildings for new uses is quite an old concept; the idea of adaptive reuse first involved the structural safety of historic buildings, regardless of the typology of the buildings or the function itself; as such, it was an adaption concerning structure. Then, this function became a core idea of the adaptive reuse approach. This approach to adaptation started during the renaissance, as many religious buildings were turned to industrial or military use by considering contemporary conservation and practice. Applying any changes to suit a function is called adaptive reuse, and many theorists discussed the adaptive reuse of heritage buildings during the 19th and 20th centuries. Heritage 
and adaptive reuse theory during 19th-century restoration practices was developed by either Le Duc (1814-1879), the architect who worked as the antiquity's inspector-in-chief in France, or by the anti-restoration movement by John Ruskin and his student William Mouris (1819-1900), both of whom were orthodox, conflicted parties [8].

Viollet Le Duc restored many buildings, such as the Notre Dame, the Castle of Pierrefonds, and the Castle of Carcassonne; he added complete pieces to the heritage buildings with the same original shape. Despite his famous work, he was criticized by most of his colleagues, especially Ruskin, who called this kind of restoration "a complete destroying". His theory depended on reuse as the best way to preserve a building. In other words, its reuse should be dependent on the intended use of the historic building and the historic building's original architecture; one should simulate what the original architect would do if they were to adapt this building to its new purpose. Ruskin mostly used the original styles; for this reason, this was referred to as the Ruskin method, which was frequently criticized as disregarding the heritage authenticity. Ruskin himself called the restoration a trial to restore the people from death, so he was unequivocal that no one could restore the beauty of the heritage building as it was originally constructed; as such, theories that oppose Ruskin's depend on preventing restoration and reuse since this would preserve the beauty of the heritage building [9].

Another theorist criticized the two approaches of Ruskin and Le Duc, as Boito referred to the restoration of the monument's uniqueness or heritage building itself. Boito classified restoration into three categories: antiquities restoration for ancient heritage buildings, creative restoration for medieval era heritage buildings, and architectural restoration for renaissance and other heritage buildings. Boito's theory distinguishes the restoration from the original building; his thinking established the Italian restoration approach. In addition to Venice charter basics, which relied on his study, he said, "the conservation of monuments is always facilitated by making use of them for some 'socially useful purpose'", with total respect to their artistic and historical values, and he focused on social use, maybe because this is one use that can be implemented with or without minor changes when compared to the other adaptive reuse categories [10].

During this period (1858-1905), another theorist, with an approach that struck a balance between the two conflicted approaches of Viollet Le Duc and John Ruskin, emerged. This theorist, Riegl, focused on the distance between the creative restoration, which allows changes for use and conservative thinking. In his article, "Der Moderne Denkmalkultus: Sein Wesen und seine Entstehung", he clarified that the heritage building itself has a conflicting value, which exists since its construction. He distinguishes between the values of architecture, history, use, and other aspects. Those conflicted values let both approaches have their own logic, despite his criticism of the creative restoration; however, he ensured that reuse is an essential part of modern conservation, and his text defines the importance of maintaining the heritage buildings that had been used, with the essential intervention needed to secure people's lives. These practical considerations may affect age value, and exceptions should be kept to a minimum.

Many charters have been issued to organize how historic buildings should be dealt with, which have been issued by The International Council of Monuments and Sites (ICOMOS) [11]. In the Venice charter [12], the compatibility of the current use with its historical use was the central factor. This was then followed by the vernacular heritage charter, under the article of adaptation [13], which highlighted the suitability and responses to the proposed usage between a building and its historical use. The Burra charter reached a more profound concept in adaptive reuse regarding integrity and impacts on the historic building [14]. The use of the building, as determined by NOUH, should be taken into account in order to respect the integrity of the structure, its character, construction, and safety conditions, including its usefulness and compatibility. Finally, the adaptation must have a minimal impact on the cultural significance of the building.

Those previously mentioned charters are restricted to conserve the physical properties of the historic building. This aspect is the one which may be affected by applying energy 
consumption and thermal-comfort-achieving strategies, especially if affected by selecting an additional material as an addition to the interior of the historic building. The four respected criteria, authenticity, integrity, reversibility, and compatibility, also govern the application of those strategies [15].

After the Second World War, many heritage buildings had been lost due to the armed conflict. In this era, the United Nations founded and established UNESCO, "United Nations for Education, Science, Culture Organization", the organization which produces the manuals and books related to world heritage conservation and management. UNESCO founded ICOMOS for the heritage protection. Known as the World Heritage Convention 1972, the ICOMOS (International Center of Monuments and Sites) has made all the known charters since 1930 until now, and these charters organize dealings with heritage buildings and formulate the contemporary theory of conservations. Both UNESCO and ICOMOS, through the World Heritage Center, deal with conservation theorists all over the world such as Jukka Jokilehto and Bernard Fielden, who are the authors of conservation and management manuals, and Christina Cameron, the professor of Heritage conservation. The World Heritage Center also considers the most contemporary theorists in this field in addition to Mechtild Rössler, the director of the World Heritage Center and the expert of both cultural and natural heritage, especially Jokilehto, Fielden, and Cameron, who introduced the required balance between conservation and reuse through presenting how to conserve the values and allow for the heritage perform a role in the everyday life of the local and universal communities as well [16].

Another evaluation analyzed the adaptive reuse process and divided the evaluating criteria dimensions into on-site and off-site criteria. The on-site criteria are related to the compatibility of the function with the heritage building, construction period adaptation, social significance, mixed job opportunities, and the involvement of the community, while the off-site criteria are about the design of public recreational spaces, initial cost, the involvement of local associations, improvement of the accessibility, and sustainable development goals [17].

\section{Adaptive Reuse in Relation to Thermal Comfort and Energy Performance}

In relation to energy efficiency in heritage buildings, many studies showed how this thinking could be used in heritage buildings containing a material designed to achieve thermal comfort [18]. In addition to the ventilation elements and wall thickness, most of the studies focused on building envelope modifications and enhancing heat performance levels, which is the opposite of what is required in Egypt. Based on those studies, guidelines appeared regarding the adaption of heritage buildings, considering sustainability as a merged set. In China, in 2010, the international conference on sustainable buildings and risk management was held. In one of the proposed studies, the green adaptation of heritage buildings was raised as a suitable strategy to extend the heritage buildings' age and reduce the carbon footprint on the contextual environment [19]. In 2011, a new design and evaluation tool was developed, called AdapSTAR, which contributed to the integrated criteria of the green design of heritage buildings, similar to the LEED "Leadership for Energy and Environment Design" system, which consists of economics, physical, technological, social, legal, and political categories. These categories gain points when the building succeeds. However, despite this approach's success, it was never universally applied [18].

Some research proved that neglecting the climate could produce some risks, so those expected risks should be predefined. Direct discussions with the users of the historic building can help identify those risks, such as using the cooling system instead of heating, related accumulative costs, and discomfort which causes performance risks. [19].

Under the UNESCO (United Nations for Education, Science, and Culture Organization) regional office, the UNDP (United Union for Preserving Nature) Croatia program published a guideline for the energy management of heritage buildings. As a national step towards achieving the energy efficiency of the listed buildings, Croatia declared a law to force the consideration of energy efficiency in heritage buildings with evaluation certifi- 
cates [20]. In 2014, another guideline (Italian Association of Air Conditioning), "Associazione Italiana Condizionamento dell'Aria Riscaldamento e Refrigerazione-AICARR", was created to evaluate and enhance energy efficiency in heritage buildings. The AICARR Guidelines "Energy Efficiency in Historic Buildings" (issued February 2014) provide information to assess and improve the energy performance of historic buildings. AICARR consists of two parts: one for the monitoring organization, which includes the energy consumption basics; the other is for designers and is oriented to the review and energy efficiency enhancement of heritage buildings [21]. In the book Solutions of Historic Buildings' Energy Efficiency, published in 2015, a team of multi-disciplinary researchers proposed integrated guidelines that adapt the energy efficiency of heritage buildings. These researchers suggest intervention methods that respect the outer structure and heritage building envelope, user's thermal comfort, and energy efficiency, which are explained through eight case studies from the Efficient Energy for EU Cultural Heritage (ENCULT) research project that bridge the gap between conservation and climate protection and was named by its author Troi, A. in his study named "Energy Efficiency Solutions for Historic Buildings"; it presented measures, results, and designs presented in relation to the modification that had been applied to heritage buildings, which makes this book an important reference for the selection of materials and intervention methods [22].

In some cases, a tailored methodology is needed to suit the varied uniqueness of each historic building, and a monitoring part can be conducted as a future study by integrating sensors that can inform the indoor status and reflect the level of the thermal comfort. In addition to the suitable environment of the historical materials, a set of technologies can hypothesize how to control indoor and thermal comfort levels without negatively impacting the historic building, an iterative monitoring process needed to decide about the timing of intervention and preventive conservation which is essential to an adapted historic building [23].

Another approach used by researchers was the Analytic Hierarchy Process (AHP)AHP is a method for organizing and analyzing complex decisions using math and psychology to produce alternatives for reusing heritage buildings. This approach was developed to be flexible and to suit the uniqueness of various heritage buildings. From another perspective, an evaluation has been made for the environmental efficiency of heritage buildings - more specifically, for evaluating the strategies of adaptive reuse, with those strategies being assessed in relation to occupancy level and to study the occupancy impact on building lifecycle economics and environmental aspects. The cases presented in the study compared the different scenarios of energy efficiency and occupancy level to support the decision-making process in choosing the best solution for adaptive reuse [24].

An overall improvement of energy consumption is a reachable target in historic buildings, as it is mostly designed with good ventilation and daylight, so the consumption thinking not a new idea for this category of building. A case study was an essential step as adaptive reuse is not so common practice, so a flexible approach based on the circumstances of the building itself can be a keystone for generalizing this thinking of historic buildings [25].

\section{Simulating Heritage Buildings' Adaption in Relation to Energy Performance, Ventilation, and Sustainability}

Most frequently, studies of heritage building reuse are focused on some specific analysis that defines the useful suggestions needed to enhance the performance of heritage buildings and evaluate the expected impact on a heritage building. In the case of demand changes to reuse the building, for example, adding materials that enhance the energy performance of the building envelope, changing the windows, or adding a cooling or heating system. This raises the issue of heritage building restrictions, as a heritage building with decorations could not permit the addition of any elements that might run counter to the original features. Research activities were conducted to find a method of keeping the values of the original features and fulfilling the function; most of these methods depended on simulations and mathematical calculations [26]. 
Choosing the correct indoor environment strategy very prior to the historical materials, many studies depend on combined approaches between the simulation and numerical measures, so computing the existing case and the expected one can achieve a better environment for the material so it can preserve the and sustain the components of the historic building. This simulation can highlight the leading causes of deterioration connected to thermo-physics, so any risky zones which need different climate control can be addressed [27].

In 2013, a researcher studied the light and heat efficiency of a historic monastery, which was transformed and adapted as a fashion show hall in Florence, Italy, where an addition was applied to the ceiling. The energy and thermal comfort efficiency was evaluated by Thermal Analysis Software (TAS), the simulation and modeling tool. Another monastery in Barcelona was analyzed by mathematical analysis to study the heat resistance of walls and sunray penetration through windows to reduce heat and decrease air-conditioning device use. Another study focused on simulations with a careful selection of the building's materials, which addressed several alternatives for the building envelope treatment. This study determined that it was possible to transform a historic building into a hotel without affecting the heritage value and reduced the energy consumption by $34 \%$ compared to the expected energy consumption rate for running a hotel, as proven in that research [28].

Another study was conducted in Egypt in 2018 at one of the Alexandria heritage buildings, addressing its adaptive reuse and putting forth different alternatives for energy consumption by simulating other options and producing energy from solar cell units [29].

\section{Heritage Buildings' Adaptive Reuse of Case Studies Review Analysis}

In this section, three historical buildings that have been reused nationally and internationally and investigated by other researchers previously are reviewed in Table 1. Our analysis in this research for these case studies will cover the following:

(1) The original use of the building and its construction year;

(2) The reuse function of the building and its retrofitting year;

(3) Architectural description of the building and its heritage value;

(4) Retrofitting level;

(5) Owner, location of the building, and its area;

(6) Energy Retrofitting Strategies, if any, and the used software to analyse the energy performance and thermal comfort;

(7) Improvement of the efficiency of energy systems.

This will help in outlining the investigation process of the current research generaly and for its case study specifically. In addition, the output of this analysis will aid the discussion and the analysis of the current research. This aim of this analysis is to figure out the most important construction and design elements that can enhance the thermal performance of the historical building and that can help in energy saving.

From the previous cases analysis, it is revealed that it is not necessary for the heritage value, which is represented by the buildings and retrofitting, to be conflicting if well designed. In addition, the strategies of retrofitting and adaptive reuse which respect the naturality of those traditional building can vary from deep and low intervention according to the sensitivity of the value. Despite the fact that it can add some limitation to the adaptive reuse, the original materials should be kept. Most of the cases changed the windows and depended on software to simulate the buildings before and after the intervention. The multiple approach of adaptation respecting the retrofitting concept could be more practical than adopting single intervention methods, the thermal comfort has a good level while the construction walls are thick, as shown in the following analyzed case study by the authors. Finally, uncareful adaptation and retrofitting to achieve better thermal comfort and energy efficiency can destroy the heritage values. 
Table 1. The analysis of three case studies for historical buildings [30-35]

Shubra Palace, KSA Antoniadis Villa, Egypt

Basmane Semt Merkezi, Turkey

In 1858 , the building has been constructed. It

consists of a two-storey building. In 1905, Ali Pash the former sharif of Mecca, rebuilt the house [30]

\section{Year of construction}

\section{The project area}

$420 \mathrm{~m}^{2}$

\section{Project Location}

Project owner

The original use of the project

A former summer resort for King Abdul Aziz [31]

Residential
In 1890, according to signed plan for

construction by the Greek architect Pericles Lascaris [29].

48 hectares with its gardens, while the villa building is made of a ground floor of $1065 \mathrm{~m}^{2}$,

a first floor of $792 \mathrm{~m}^{2}$, a roof of $202 \mathrm{~m}^{2}$, and a basement of $343 \mathrm{~m}^{2}$, with a total floor area of $2400 \mathrm{~m}^{2}$.

Alexandria, Egypt

Basmane district, Izmir, Turkey

Bibliotheca Alexandrina private owner

The Villa Antoniadis was used as a guest house, such as the kings of Belgium, Greece, and Italy [29]. early nineteenth century [24]

$380 \mathrm{~m}^{2}$ merchant class and noble families [35].

The building was designed for a residence 
Table 1. Cont.

Shubra Palace, KSA

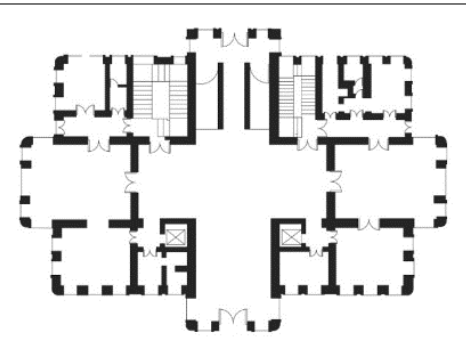

The Plans

Ground and first floor levels (office and work) [32]

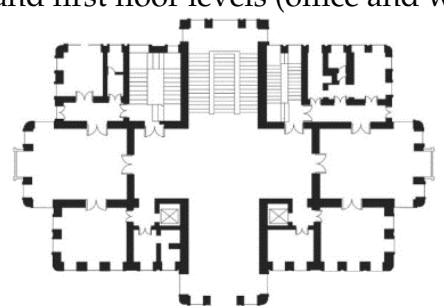

Typical design for second and third levels [32]
Antoniadis Villa, Egypt

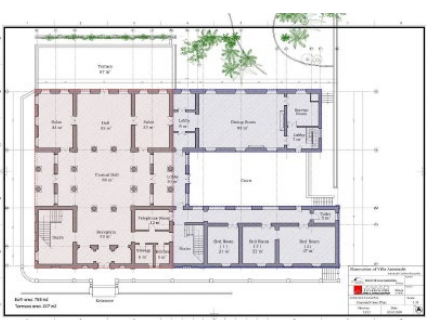

The ground floor [34]

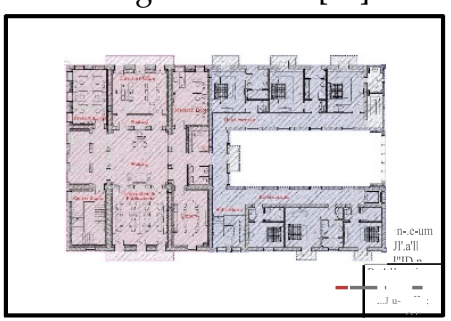

The first floor [34]
Basmane Semt Merkezi, Turkey
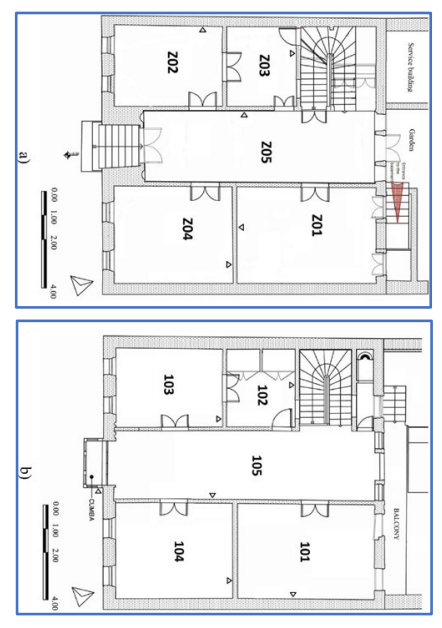

The ground floor [35]

The first floor [35]

Shubra Palace is one of the most important

historical buildings in Al-Taif City and Saudi

Arabia [35]. The Museum building now consists of

four floors and four uniform facades with gardens.

The openings and the attached open spaces or

"Terraces" are decorated with a criss-crossed

pattern of strips of wood "latticework". The floors

Introducing the project and its

are covered with marble from Carrara, Italy [30]. A

large entrance hall is located in the ground floor with four engraved columns. There are also two

halls leading to the palace rooms and a large

staircase leading to the second floor that features

two suites. Stone is the main material used in walls

with cladding, plaster, and sap extracted from sugar

cane. The wooden doors and lattice windows

demonstrating a high level of mastery in terms of manufacture and detail [33].

The building consists of three floors with an internal wooden staircase connects the floors

The Antoniadis Palace and its park lies at the southern entrance of Alexandria and is together. The entrance to the ground floor has a staircase from the garden.

surrounded by some 48 hectares of landscape. It has a large window called a cumba with a The Antoniadis gardens include historic statues and a tropical greenhouse.

Archeological remains exist at the site,

Turkish heritage part of the building; the rest

of the windows of the building are wooden

frame and glass windows. The building has a

central heating system by which the building

is heated using a red fuel hot water boiler [24] 
Table 1. Cont.

\begin{tabular}{|c|c|c|c|}
\hline & Shubra Palace, KSA & Antoniadis Villa, Egypt & Basmane Semt Merkezi, Turkey \\
\hline Retrofitting year & 1995 & 2015 & 2000 \\
\hline
\end{tabular}

Muesum.

The exhibition halls represent three major periods

\begin{tabular}{ll}
\hline Retrofitting level & Standard Retrofitting \\
\hline Retrofitting goals & Reusing the building as a museum \\
\hline
\end{tabular}

Software of before Islam. These are: The Stone Age to Jahiliya period; Islamic heritage; and the unification of the Kingdom. In addition to many valuable artefacts [32]. TAS EDSL energy model
The retrofitting strategy kept the stone as the main materials of the walls with its high thermal mass. The windows were sealed to protect the palace and to switch the mode of the building to fully air conditioned.
The "Alex-Med" Alexandrian-Mediterranean research center of "Bibliotheca Alexandrina" [29]

Deep retrofitting

Reusing the building as

Alexandrian-Mediterranean research center of Reusing the building as a hotel "Bibliotheca Alexandrina".

Design Builder software

The project depended on the following steps in order to achieve energy efficiency and thermal comfort; those steps are: (a) adding thermal insulation, (b) exterior openings double glazing, (c) adding shading to the atrium, (d) internal lighting control, (e) using natural ventilation, $\mathrm{f}$ ) adding photovoltaic panels on the roofs, (g) simulating the project with all the suggested modification to determine the overall energy efficiency achievements [34].

Alwetaishi et. al. [32] confirmed in their

investigation that the use of thermal mass helped to provide thermal comfort to the users. The thermal comfort zone is achieved most of the year. The thermal mass helped to keep the external envelops cool in most of the seasons and in most of the orientations in summer, which can help to utilize the advantage of natural ventilation system and to get ride off the air-conditioning system for long time [32].
The results show a 56\% improvement in lighting energy consumption. Cooling energy consumption decreased by $9.1 \%$ and heating energy consumption increased by $16.8 \%$ due to the decrease of the heat gain produced from artificial lighting. However, the overall energy use intensity is improved by $23.9 \%$ [34].

\section{Basmane Semt Merkezi Hotel}

\section{Deep retrofitting}

Design Builder software

The Energy Strategy was reducing consumption by $40 \%$ of the total annual energy consumption and preserving heritage values by making minor physical changes to the building and not making any visible change in the appearance of the building [24]
Improving the efficiency of energy systems 


\section{Materials and Methods}

A multi-techniques methodology is employed in the current research. These techniques include a directed questionnaire with closed-ended questions, a simulation, and an analytical literature review, including previous cases studies. The latter was used to review the relevant literature and build a preliminary theory on the adaptive reuse of historical buildings. In addition, the questionnaire and the simulations are employed to cover the Post Occupancy Evaluation (POE) strategy, which depends on combined techniques, including both the objective and the subjective assessments. The simulation approach as a tool of behavior representation of a historic building through Design Builder software and Autodesk-Ecotect is used to conduct the objective assessment. At the same time, the questionnaire tool is applied to measure the occupants' responses to cover the subjective assessment part.

A full simulation study should be applied to define the environmental conditions of any historic building before adaption because several heating and cooling scenarios can be implemented, so a simulation study can assess the decision to assign the suitable procedure to achieve thermal comfort and save unnecessary energy usages. [36]. The simulation was used to test the case study's thermal performance during the main seasons (summer and winter). It is worth mentioning that many researchers have utilized this methodology $[24,35]$. First, the Weather Tool software was used to analyze and visualize the hourly climatic data of the location. Second, the Design-Builder and Ecotect 5.6 software were used to model and test the case study's thermal performance. The hourly air temperature degrees inside one of the building's central zones were simulated on 15 July, representing the year's hottest day; in contrast, 27 February was used to represent the coldest day of the year. The simulated air temperature degrees were statistically compared with each other in addition to the outside air temperature, providing a clear understanding of the effect of the building materials and design on its thermal performance during the two seasons; this measure was taken to help determine both a suitable adaptive reuse decision and the reasonable consumption of energy when considering the consumption rates and comfort levels.

The questionnaire addressed the occupants of the building (14 persons) to ensure a complete sample. The questionnaire had 23 questions divided into 2 sections. The first part consisted of eight questions that measure the dress code and thermal perceptions; the second part, which ranged from questions 9 to 23, discussed the state of the adaptive reuse of the building regarding its suitability for its intended use, the philosophy behind the adaptation, possible conflicts between adaption and historic buildings, limitations regarding work requirements, and so on. A predictive correlation model was developed to assess the adaptive reuse quality parameters achieved through crosstab and correlation analysis. These measurements were extracted from the international charters of heritage adaptive reuse issued by the International Council of Monuments and Sites (ICOMOS). Consequently, the questions could be classified into 4 categories as listed in Table 2.

The analysis of the questionnaires' results was performed using the Statistical Package for the Social Sciences (SPSS). To determine the purposive sample, two tests were applied. The first involved a crosstab descriptive test in describing the direct relation of the sample. In contrast, a predictive correlation test was used to reveal the main correlated variables to be considered when adapting a historic building for reuse; these relations determined that some items were to be considered more than others and showed some strong correlations between those elements.

The answers to the thermal comfort questions determine the Predicted Mean Vote (PMV) and the Predicted Percentage of Dissatisfied (PDD) indices. The PMV index is defined by the Chartered Institution of Building Services Engineers [29] as "the mean value of the votes of a large group of persons, exposed to the same environment with identical clothing and activity." In contrast, PPD predicts the percentage of unlikely occupants to be satisfied with the thermal conditions. Dissatisfaction values on the PMV scale range from -3 to +3 [37]. 
Table 2. Categories and questions of the designed questionnaire, by the authors.

\begin{tabular}{|c|c|c|}
\hline \multirow[b]{2}{*}{ - $\quad$ Section 1} & - $\quad$ Personal & $\begin{array}{ll}- & \text { Age Q1 } \\
\text { - } & \text { Gender Q2 }\end{array}$ \\
\hline & $\begin{array}{l}\text { - } \quad \text { Thermal comfort } \\
\text { - ASHRAE }\end{array}$ & $\begin{array}{ll}\text { - } & \text { Clothing Q3 } \\
\text { - } & \text { Activity Q4 } \\
\text { - } & \text { Duration Q5 } \\
\text { - } & \text { Thermal sensation in Summer, Winter and } \\
& \text { Overall Q6-8 }\end{array}$ \\
\hline \multirow{4}{*}{ - $\quad$ Section 2} & $\begin{array}{l}-\quad \text { USE } \\
\text { - Le Duc, ICOMOS, Venice charter, Riegl, } \\
\text { Jokilehto, Fielden }\end{array}$ & $\begin{array}{ll}\text { - } & \text { Suitability of use Q9 } \\
\text { - } & \text { Context and suitability to use Q15 } \\
\text { - } & \text { Limitation of the space Q17 } \\
\text { - } & \text { Usefulness of use Q21 } \\
\text { - } & \text { Compatibility of use Q } 22\end{array}$ \\
\hline & $\begin{array}{ll}\text { - } & \text { Values } \\
\text { - } & \text { Ruskin, ICOMOS, Bioto, Jokilehto, Fielden }\end{array}$ & $\begin{array}{ll}\text { - } & \text { Values and conflicts Q11 } \\
\text { - } & \text { Atmosphere of the space Q16 } \\
\text { - } & \text { Values safety Q20 }\end{array}$ \\
\hline & $\begin{array}{ll}- & \text { Material } \\
- & \text { ICOMOS }\end{array}$ & $\begin{array}{ll}\text { - } & \text { Material and function Q12 } \\
\text { - } & \text { Material and design philosophy Q13 } \\
\text { - } & \text { Material and thermal comfort Q18 }\end{array}$ \\
\hline & $\begin{array}{ll}\text { - } & \text { Adaptation } \\
\text { - } & \text { ICOMOS, Burra charter }\end{array}$ & $\begin{array}{ll}\text { - } & \text { Conservative approach of adaptation Q14 } \\
\text { - } & \text { Response to constraints Q18 } \\
\text { - } & \text { Integration with structure Q19 } \\
\text { - } & \text { Impact of the adaption Q23 }\end{array}$ \\
\hline
\end{tabular}

The PMV /PPD index uses different human and environmental factors that affect thermal comfort [29]. It has been adopted in British, European, and international standards [38]. According to the American Society of Heating, Refrigerating, and Air-Conditioning Engineers (ASHRAE), the PMV / PPD indices combine the effects of air temperature, mean radiant temperature, air movement, and humidity with clothing and activity levels into one value on the thermal sensation scale-see Figure 1 [39].

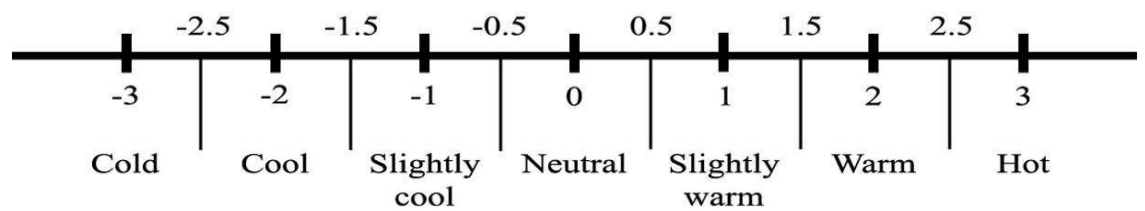

Figure 1. The thermal sensation seven-point scale, after American Society of Heating, Refrigerating, and Air-Conditioning Engineers (ASHRAE) (ASHRAE 2005).

\section{Case Study Adaptive Reuse of Military Building in Cairo Historic Citadel}

Islamic civilization created its unique urban heritage throughout many eras of history; however, a common concern in all of those eras was how to defend the city against enemies, leading to the construction of defense buildings such as the Citadel. There is a notable difference between the Citadel, which is the case study chosen for this research, and other complexes found in Islamic cities that are characterized as typical urban heritage structures, designed with narrow alleys to create shade and shelter the town from strong winds. The Citadel depends on its wide spaces between buildings, creating a different airflow (Figure 2). 

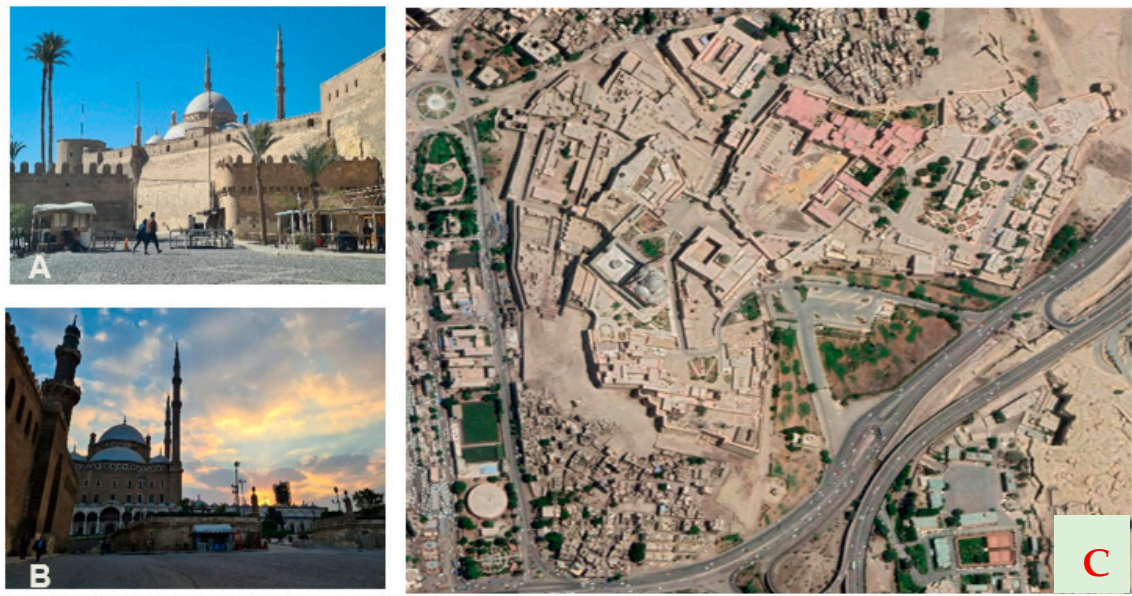

Figure 2. The urban setting of the Cairo Citadel, the context of the chosen case study on the right-hand side while (A) the main entrance; (B) Mohamed Ali Mosque (C).

The Citadel is an architectural complex referred to as the mountain citadel; it is located in Cairo, Egypt. Its site was chosen carefully due to its strategic location. From that height, Cairo can be observed in its entirety from the Citadel, as it is located on a high, rocky mountain, making it difficult for anyone to climb it without being seen; in 1176, this complex was established by Salah Al-Din Al-Ayoubi and has been listed as an archeological site since 1951 under no 556 [40] (Figure 2).

A historic building in the Citadel was chosen as the case study, which is a soldiers' housing unit called koshlaq four, and is currently used for administrative and cultural purposes. This building was established in Muhammad Ali's era and restored in Said Pash's era, but some changes were made to the original design; for example, all the void ducts connected to the north wall of the Citadel were closed. The Citadel is no longer a residence for soldiers and has deteriorated a lot because of the lack of maintenance. The new use of this building started in 2004 after the last restoration process, which began in 2001, the nature of use depends on movable furniture to perform administrative work related to the urban harmonization of valued districts. This function interfered at the building at the minimum level with durable materials as mentioned before at the changes applied to the heritage building.

The koshlaq four building consists of two floors. The structure involves barring walls made of stone. The first floor is made of carved limestone with a height of $4.7 \mathrm{~m}$, and the second floor, with a height of $4.5 \mathrm{~m}$, is made of various types of stone with wooden beams and has been plastered. In the middle of the second floor, there is a Qamariah (the red square in Figure 3), which was added in during the previous restoration. The windows are symmetric in the facades, and the door is in the middle. Another condition of the koshlaq design is that the facade length should be 3-5 times the height. The building has two doors; the main entrance is in the west facade, with a circular arch at the top and a height of $3 \mathrm{~m}$ and a width of $1.52 \mathrm{~m}$. The second door was not found in the original plans in the north facade; it now has the same design and dimensions as the main door. According to the original plans, some differences can be seen in the ground plan; some spaces have been divided into smaller spaces, and some facilities have been added, such as the toilets and the stairs. The building has various ventilated elements, such as the Qamariah, Shokhshikha, and a backyard court. 


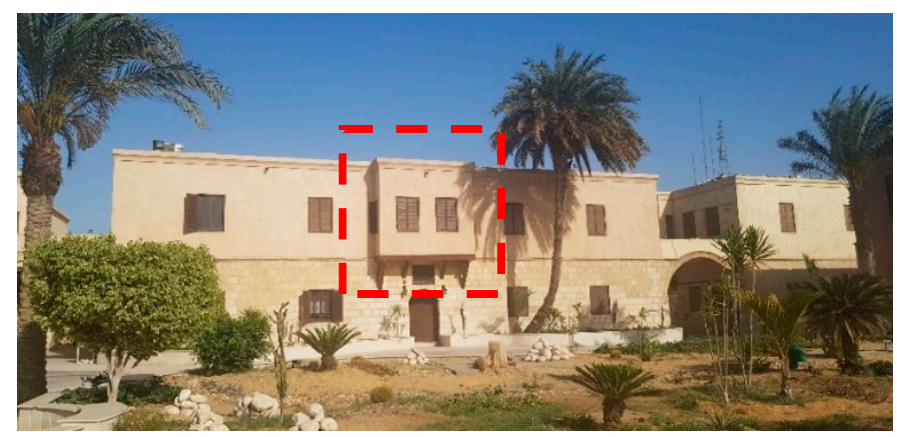

Figure 3. The Western façade, including the main entrance-the Qamariah is in the red square.

The original design of the buildings depends on natural ventilation, which depends on opening the Shokhshikha (the blue square in Figure 4); in addition, the cross ventilation comes from the windows, and a small amount of open space exists in the backyard of the building, which helps in cycling the air through the multi-directional air tower "the Shokhshikha". Thus, the building orientation itself reflects its defensive purpose rather than any environmental purpose.

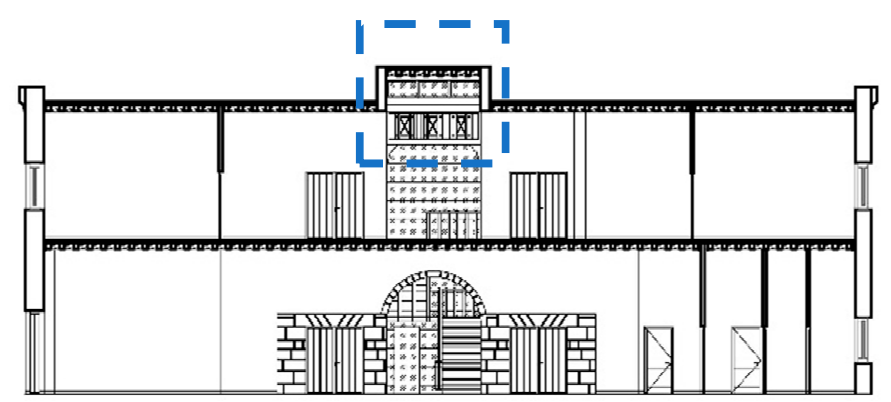

Figure 4. The cross-section for case study building-the Shokhshikha is in the blue square.

The case study's thermal behavior differs from one season to another. Therefore, the advantages of the room orientations vary according to the season; the sun is the primary heat source. The building is comprised of weight-bearing walls made from stone with wooden beams, ceilings, and windows.

This building (Figures 3-5) underwent many restoration processes; the last was in 2001, and since that time, it has been under the control of the National Organization for Urban Harmony. This administrative organization belongs to the ministry of Culture [41].
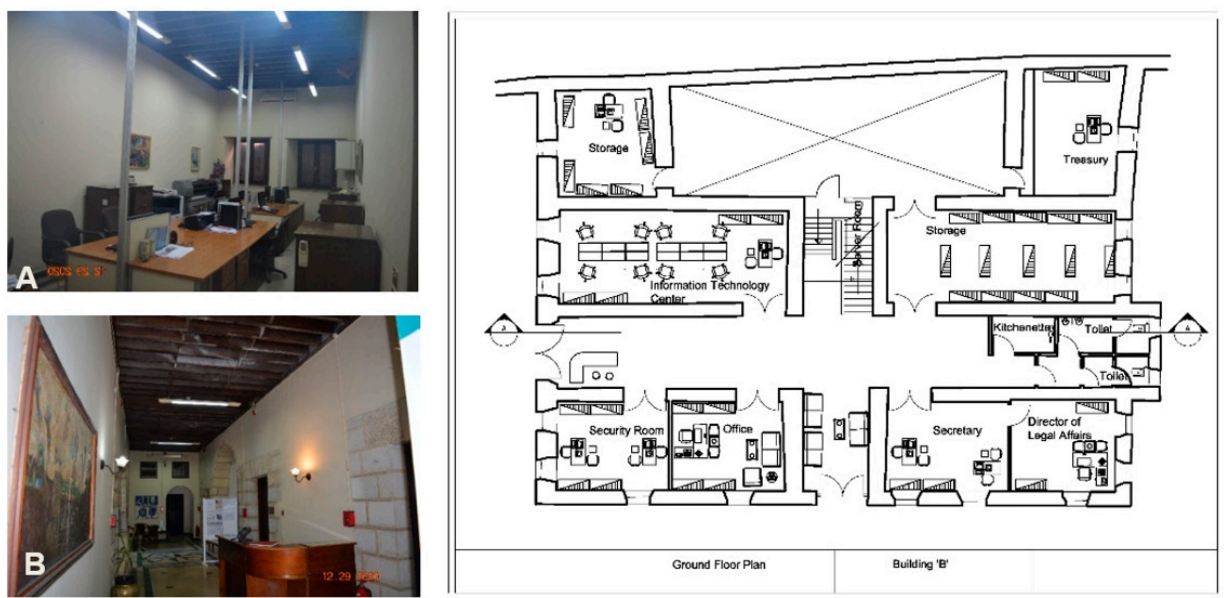

Figure 5. The ground floor plan for the case study building on the right-hand side while: (A) working place; (B) the corridor shows offices doors. 


\section{Analysis, Results, and Discussion}

The POE revealed a set of essential findings, revealing that the current heating/cooling scenario is not correct. This is described in detail in the following subsections.

\subsection{Simulation Analysis}

As explained in the research methodology, the purpose of the simulation was to test the case study's thermal performance during Summer and Winter. In the beginning, the hourly climatic data were analyzed using the Weather Tool software. This tool visualizes the hourly air temperature for the entire year and determines the comfort range using several approaches. In this research, the adaptive free-running model by Humphreys was used.

By analyzing the hourly climatic data for the "Helwan city, Egypt" file, obtained from the United States Department of Energy (US DOE) and installed in the main library of Design-Builder and Ecotect, it was found that the thermal comfort zone in July, based on the adaptive model for free-running buildings, ranges between 26 and $31{ }^{\circ} \mathrm{C}$ in summer. In contrast, it ranges between 18 and $22^{\circ} \mathrm{C}$ in winter (Figure 6). This gives us a wide comfort range between 18 and $31^{\circ} \mathrm{C}$ for the whole year.

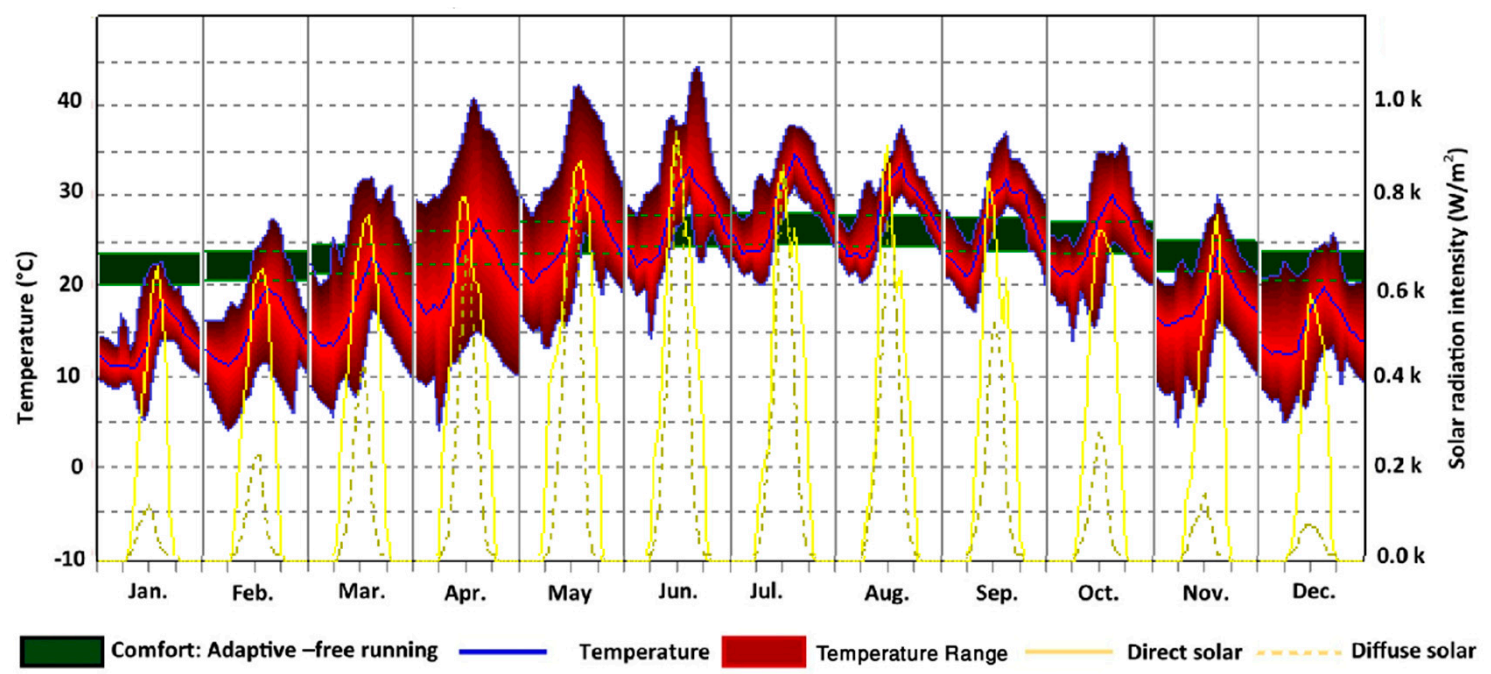

Figure 6. Analyzing the hourly climatic data file of Helwan using the Weather Tool.

After that, the simulation software (Design-Builder and Ecotect V5.6) was used to model and test the case study's thermal performance. The building was simulated as a free-running building with a natural ventilation system.

Simulation results using Design-Builder and Autodesk Ecotect show some differences in the building's thermal performance, both confirm that the diurnal temperature variation in the air temperature is minimal due to the high thermal mass of the building's walls. The air temperature inside ranges between 30.7 and $31.7^{\circ} \mathrm{C},\left(1{ }^{\circ} \mathrm{C}\right.$ difference), whereas the outside air temperature ranges between 25 and $38^{\circ} \mathrm{C}\left(13^{\circ} \mathrm{C}\right.$ difference $)$ on the same day (15 July). This confirms the thermal mass strategy's effectiveness as one of the best passive strategies for hot, arid climates (Figure 7).

The hourly air temperature degrees inside three of the building's central zones were simulated on 15 July, representing the year's hottest day. The hourly air temperature on 27 February was used for the coldest day of the year. Statistically, the simulated air temperature degrees were compared with each other in addition to the outside air temperature. This clarifies the building materials' effect and design on its thermal performance during the two main seasons (Figure 8). 


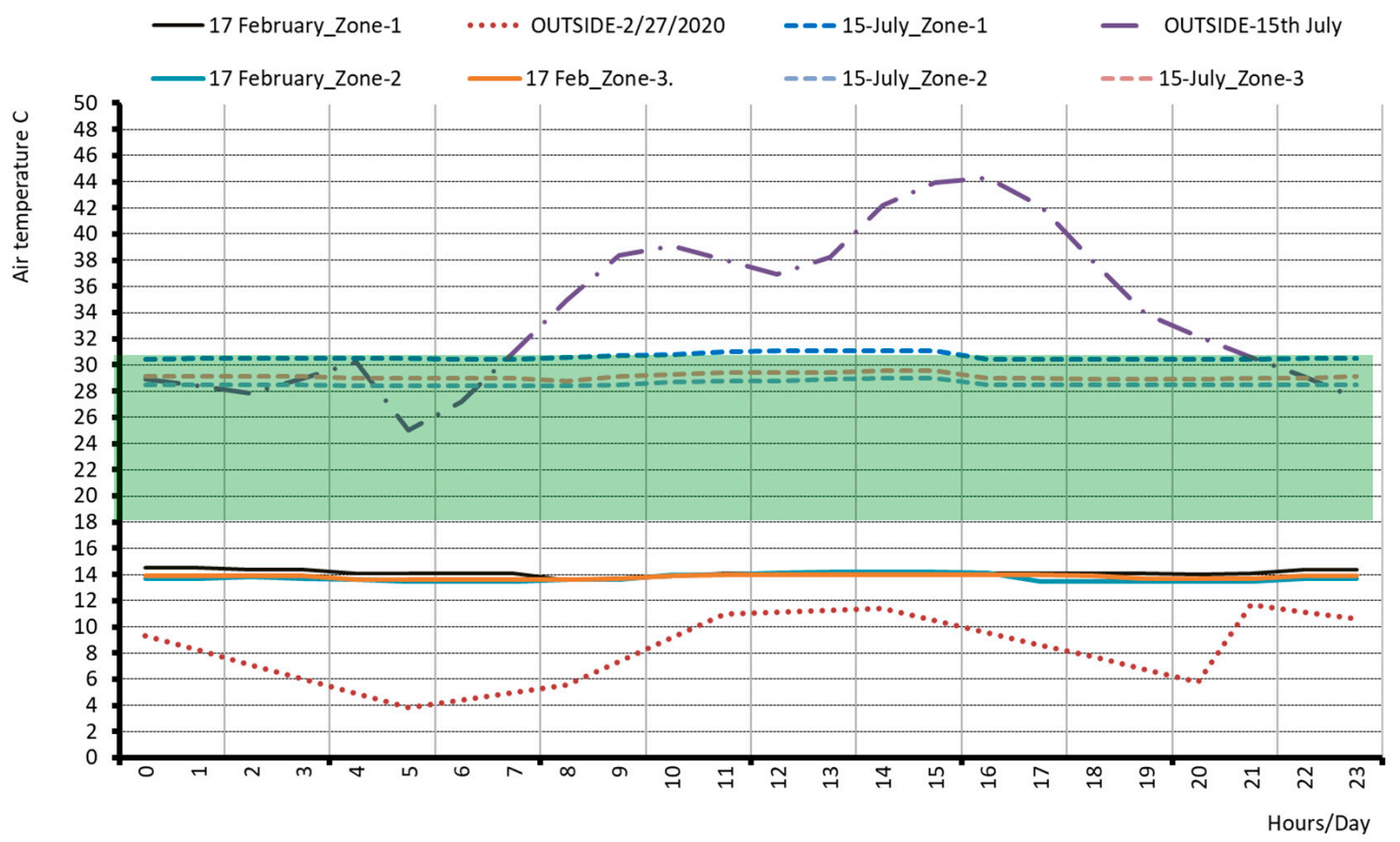

Figure 7. Simulated internal air temperature degrees inside three of the main zones of the case study on 17 February and 15 July.
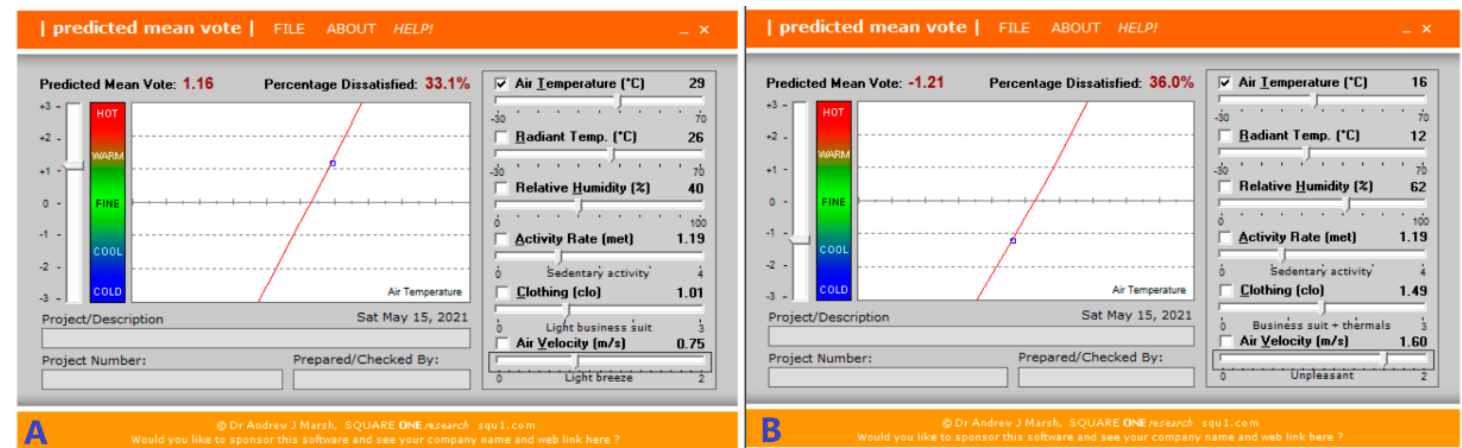

Figure 8. Predicted Mean Vote (PMV) (A) for summer and (B) for winter using Cardiff PMV Tool.

Upon comparing the hottest and the coldest days of the same zone in the building (Zone-7) using Autodesk Ecotect (Figure 8), it was found that the highest air temperature on 15 July (the hottest day) was $30.5^{\circ} \mathrm{C}$, whereas the lowest air temperature on 27 February was $13.5^{\circ} \mathrm{C}$.

Surprisingly, the hottest air temperature degree is found to be within the summer comfort zone, while the coldest air temperature degree is lower than the comfort zone in winter by $4.5^{\circ} \mathrm{C}$.

Part of the survey that has been conducted with the building's occupants addressed their thermal sensation. They confirmed that they feel discomfort in the building during the winter season. They added that the building is not exposed to solar radiation from any side. The Citadel fence is almost at the same height as the building, and the urban combat fabric prevents the penetration of solar radiation during the winter season.

The occupants' responses from the survey revealed that occupants felt warm during summer and cool during the winter, with a Predicted Mean Vote (PMV) equal to 2.21 and -1.89 , respectively. This confirms the building's excellent performance since few occupants reported that they feel hot in the summer and cold in the winter. To check the validity of these results, they were compared via objective assessment using the Cardiff PMV Tool's simulated data. The average simulated data on the building's thermal performance in January and June were chosen to represent the winter and summer, respectively. These 
data include air temperature, Mean Radiant Temperature (MRT), air velocity, and humidity levels. The occupants' data regarding activity rates and clothing levels were collected from the occupants during the survey (Table 3).

Table 3. Environmental and human thermal factors in winter and summer.

\begin{tabular}{ccc}
\hline Parameter & Summer (June) & Winter (January) \\
\hline Air temperature $\left({ }^{\circ} \mathrm{C}\right)$ & 28 & 16 \\
MRT $\left({ }^{\circ} \mathrm{C}\right)$ & 26 & 13 \\
RH $(\%)$ & 40 & 62 \\
Air velocity (m/s) & 0.75 & 1.6 \\
Activity level (met) & 1.19 (Seated-sedentary) & 1.19 (Seated-sedentary) \\
Clothing rate (Clo) & 1 (Light business suit) & 1.49 (Business suit + thermal) \\
\hline
\end{tabular}

The comparison revealed some differences between the subjective and the objective assessments. The PMV in winter shows that the subjective PMV $=-1.89$ and the objective $\mathrm{PMV}=-1.21$, indicating that the occupants feel slightly cool/cool. The difference in the subjective/objective PMV during the summer is more significant (subjective PMV $=2.21$ and objective PMV = 1.15), indicating that the occupants feel warm/hot and slightly warm, respectively (Figure 8 ).

The authors of this research believe in the building's comfortable thermal performance during the summer due to its high thermal mass and acceptable air velocity levels. The simulation results obtained using Design-Builder and Autodesk Ecotect, in addition to the Cardiff PMV Tool, confirmed the authors' assumptions. Moreover, based on the authors' experience and previous research into hot climates, occupants of other buildings frequently report their thermal sensation as very hot. However, the occupants of this building reported that they were only warm, confirming the acceptable thermal performance of the building. People do not believe that passive strategies in buildings can significantly reduce the air temperature in summer. They install air conditioning systems and use these systems during summer without allowing themselves to open the windows or install fans. By analyzing the required monthly cooling and heating loads for the building (Figure 9 and Table 4) based on the adaptive model for free-running buildings $\left(18-31^{\circ} \mathrm{C}\right)$, it was found that the cooling needs are minimal compared to the heating loads.

Table 4. The required cooling and heating loads for the building per month.

\begin{tabular}{cccc}
\hline \multicolumn{4}{c}{ Comfort: Adaptive-Free Running $( \pm \mathbf{1 . 7 5})$} \\
\hline \multicolumn{4}{c}{ Max Heating: 36,383 W at 10:00 on 29 January } \\
\hline Max Cooling: 38,944 W at 15:00 on 13 June \\
MONTH & HEATING & COOLING & TOTAL \\
January & $($ Wh $)$ & $($ Wh $)$ & Wh $)$ \\
February & 886,837 & 0 & 886,837 \\
March & 705,582 & 0 & 705,582 \\
April & 374,248 & 0 & 374,248 \\
May & 150,550 & 41,990 & 192,541 \\
June & 0 & 0 & 0 \\
July & 0 & 320,307 & 320,307 \\
August & 0 & 190,146 & 190,146 \\
September & 0 & 22,653 & 22,653 \\
October & 0 & 0 & 0 \\
November & 0 & 0 & 0 \\
December & 157,242 & 0 & 157,242 \\
TOTAL & 724,469 & 0 & 724,469 \\
PER M ${ }^{2}$ & $2,998,930$ & 575,096 & $3,574,026$ \\
\hline
\end{tabular}




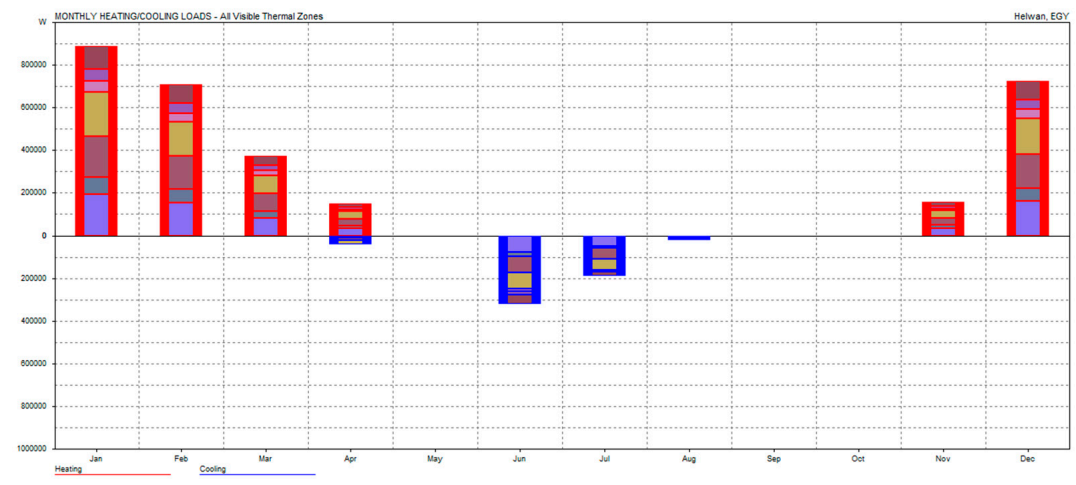

Figure 9. Cooling/heating loads of the building by the authors.

The building needs $575 \mathrm{kWh}$ for cooling in summer and $2998 \mathrm{kWh}$ for heating in winter.

\subsection{Survey Analysis}

The survey analysis consists of two parts: the first is a crosstab descriptive test, which shows both the chi-square significance indicator in relation to symmetric measures and opinion analysis; the second part is a correlation coefficient predictive test, which yields the correlation significance and addresses the strength or weakness of the relation applied to the set of adaptive reuse indicators.

\subsubsection{Survey Analysis Crosstab}

Crosstab summarizes the relationship between different variables of categorical data. As the basic crosstabs in SPSS command give counts by default, this test was applied to describe the set of questionnaire results that were used to determine the adaptive reuse status. Most of the responses ensure the suitability of the procedures for a historic building, as shown in the questions listed in the following table. The impact of the adaptation on this historic building is minimal. Many of the other crosstab measures showed an association and highly correlated factors of more than 0.5 and near to 1 , which is the range for a strong correlation. This means that the multi-variables are associated and that they can be used to formulate a combined approach for the required assessment methodology (Table 5, Figure 10).

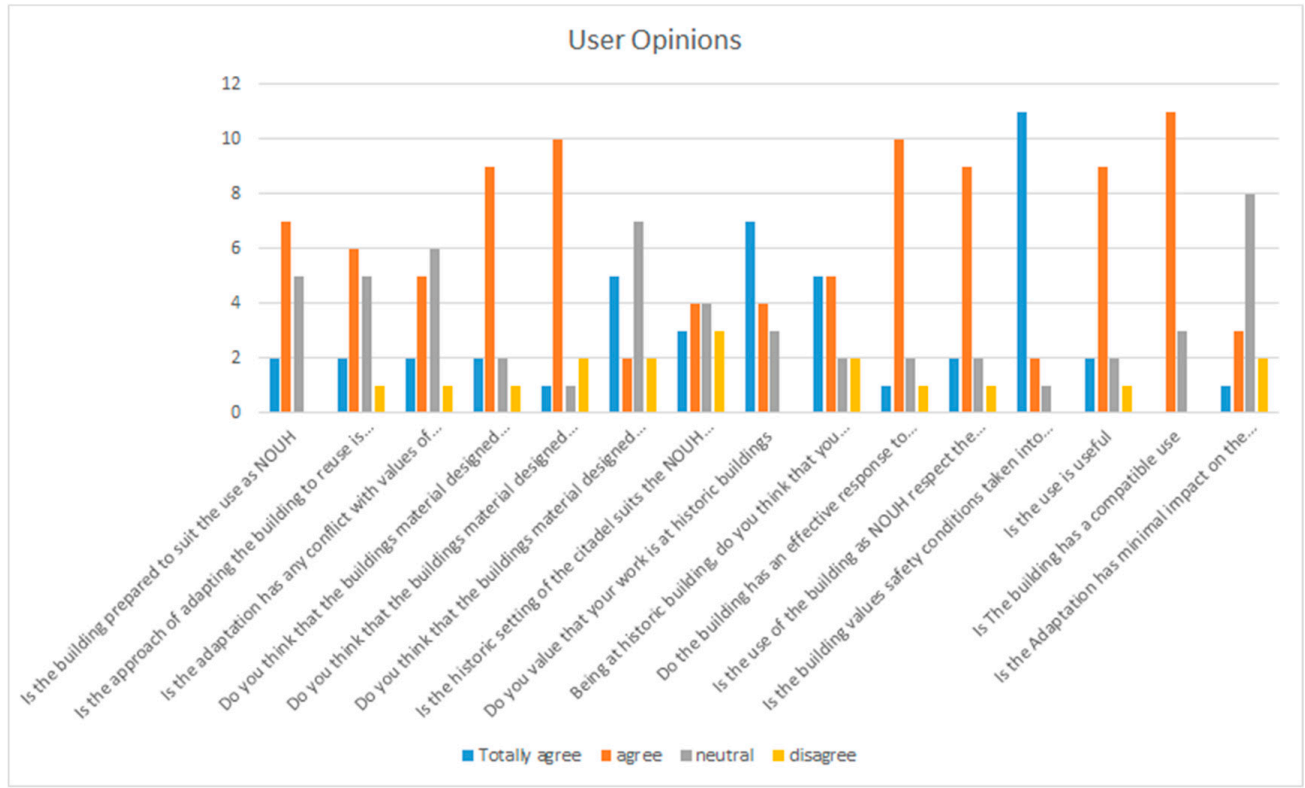

Figure 10. The descriptive analysis of users' opinions regarding the adaptive reuse questions show that the adaptive reuse approach has a positive effect. 
Table 5. Crosstab descriptive and correlation data show an association and led to the test's predictive correlation coefficient.

\begin{tabular}{|c|c|c|c|c|c|c|c|c|c|c|c|}
\hline \multirow{2}{*}{ S. } & \multirow{2}{*}{ Questions } & \multicolumn{4}{|c|}{ Opinions } & \multirow{2}{*}{$\begin{array}{c}\begin{array}{c}\text { Approval } \\
\text { Percentages }\end{array} \\
\%\end{array}$} & \multicolumn{3}{|c|}{ Chi-Square Sig. } & \multicolumn{2}{|c|}{ Symmetric Measures Sig. } \\
\hline & & $\begin{array}{l}\text { Totally } \\
\text { Agree }\end{array}$ & Agree & Neutral & Disagree & & $\begin{array}{c}\text { Pearson } \\
\text { Chi-Square }\end{array}$ & Likelihood & $\begin{array}{c}\text { Linear } \\
\text { Association }\end{array}$ & Pearson-R & $\begin{array}{c}\text { Spearmen } \\
\text { Correlation }\end{array}$ \\
\hline 1 & $\begin{array}{l}\text { Is the building prepared to } \\
\text { suit the NOUH? }\end{array}$ & 2 & 7 & 5 & 0 & $64 \%$ & 0.03 & 0.015 & 0.016 & 0.009 & 0.13 \\
\hline 2 & $\begin{array}{l}\text { Is the approach of adapting } \\
\text { the building for reuse } \\
\text { conservative? }\end{array}$ & 2 & 6 & 5 & 1 & $57 \%$ & 0.112 & 0.096 & 0.088 & 0.087 & 0.116 \\
\hline 3 & $\begin{array}{l}\text { Does the adaptation have } \\
\text { any conflict with } \\
\text { architectural or historic } \\
\text { values? }\end{array}$ & 2 & 5 & 6 & 1 & $50 \%$ & 0.129 & 0.064 & 0.62 & 0.639 & 0.519 \\
\hline 4 & $\begin{array}{l}\text { Do you think that the } \\
\text { building materials are } \\
\text { designed to achieve the } \\
\text { desired function? }\end{array}$ & 2 & 9 & 2 & 1 & $79 \%$ & 0.687 & 0.643 & 0.661 & 0.679 & 0.755 \\
\hline 6 & $\begin{array}{l}\text { Do you think that the } \\
\text { building materials are } \\
\text { designed to achieve thermal } \\
\text { comfort? }\end{array}$ & 5 & 2 & 7 & 2 & $50 \%$ & 0.73 & 0.741 & 0.468 & 0.491 & 0.507 \\
\hline 7 & $\begin{array}{l}\text { Does the historic setting of } \\
\text { the citadel suit the NOUH } \\
\text { function and work } \\
\text { requirements? }\end{array}$ & 3 & 4 & 4 & 3 & $50 \%$ & 0.99 & 0.99 & 1 & 1 & 1 \\
\hline 8 & $\begin{array}{l}\text { Do you value working in a } \\
\text { historic building? }\end{array}$ & 7 & 4 & 3 & 0 & $79 \%$ & 0.382 & 0.26 & 0.183 & 0.194 & 0.203 \\
\hline
\end{tabular}


Table 5. Cont.

\begin{tabular}{|c|c|c|c|c|c|c|c|c|c|c|c|}
\hline \multirow{2}{*}{ S. } & \multirow{2}{*}{ Questions } & \multicolumn{4}{|c|}{ Opinions } & \multirow{2}{*}{$\begin{array}{c}\begin{array}{c}\text { Approval } \\
\text { Percentages }\end{array} \\
\%\end{array}$} & \multicolumn{3}{|c|}{ Chi-Square Sig. } & \multicolumn{2}{|c|}{ Symmetric Measures Sig. } \\
\hline & & $\begin{array}{l}\text { Totally } \\
\text { Agree }\end{array}$ & Agree & Neutral & Disagree & & $\begin{array}{l}\text { Pearson } \\
\text { Chi-Square }\end{array}$ & Likelihood & $\begin{array}{c}\text { Linear } \\
\text { Association }\end{array}$ & Pearson-R & $\begin{array}{l}\text { Spearmen } \\
\text { Correlation }\end{array}$ \\
\hline 9 & $\begin{array}{l}\text { Given that you work in a } \\
\text { historic building, do you } \\
\text { think that this leads to } \\
\text { limitations in regard to } \\
\text { work, transportation, and } \\
\text { so on? }\end{array}$ & 5 & 5 & 2 & 2 & $71 \%$ & 0.739 & 0.753 & 0.354 & 0.375 & 0.395 \\
\hline 10 & $\begin{array}{l}\text { Does the building provide } \\
\text { an effective response to } \\
\text { functional, social, and } \\
\text { environmental constraints? }\end{array}$ & 1 & 10 & 2 & 1 & $79 \%$ & 0.295 & 0.295 & 0.07 & 0.067 & 0.092 \\
\hline 11 & $\begin{array}{l}\text { Does the use of the building } \\
\text { by the NOUH respect the } \\
\text { integrity of the structure } \\
\text { and its character? }\end{array}$ & 2 & 9 & 2 & 1 & $79 \%$ & 0.687 & 0.643 & 0.661 & 0.679 & 0.755 \\
\hline 12 & $\begin{array}{l}\text { Are the building's safety } \\
\text { conditions taken into } \\
\text { account? }\end{array}$ & 11 & 2 & 1 & 0 & $93 \%$ & 0.651 & 0.58 & 0.89 & 0.896 & 0.926 \\
\hline 13 & Is the building useful? & 2 & 9 & 2 & 1 & $79 \%$ & 0.626 & 0.471 & 0.26 & 0.277 & 0.229 \\
\hline 14 & $\begin{array}{l}\text { Does the building have } \\
\text { other compatible uses? }\end{array}$ & 0 & 11 & 3 & 0 & $79 \%$ & 0.837 & 0.839 & 0.843 & 0.852 & 0.852 \\
\hline 15 & $\begin{array}{l}\text { Does the building } \\
\text { adaptation have a minimal } \\
\text { impact on the cultural } \\
\text { significance of the building? }\end{array}$ & 1 & 3 & 8 & 2 & $29 \%$ & 0.336 & 0.269 & 0.399 & 0.421 & 0.287 \\
\hline
\end{tabular}




\subsubsection{Correlation Coefficient}

Correlations provide information about the relationship between two variables. The degree of correlation is (1) perfect: if the value is near \pm 1 , then it is a perfect correlation-as one variable increases, the other variable also tends to increase (if positive) or decrease (if negative); (2) high degree: if the coefficient value lies between \pm 0.50 and \pm 1 , there is a strong correlation.

The Pearson correlation can be defined as a strong correlation if it exceeds 0.5 in a range from 0 to 1 (either negative or positive). The red highlighted numbers in the following table show the significance level of the correlation. In contrast, the blue highlighted numbers show a strong positive correlation, which supports the belief that a holistic approach to adapting such historic buildings should guide similar projects (Table 6, Figure 11).

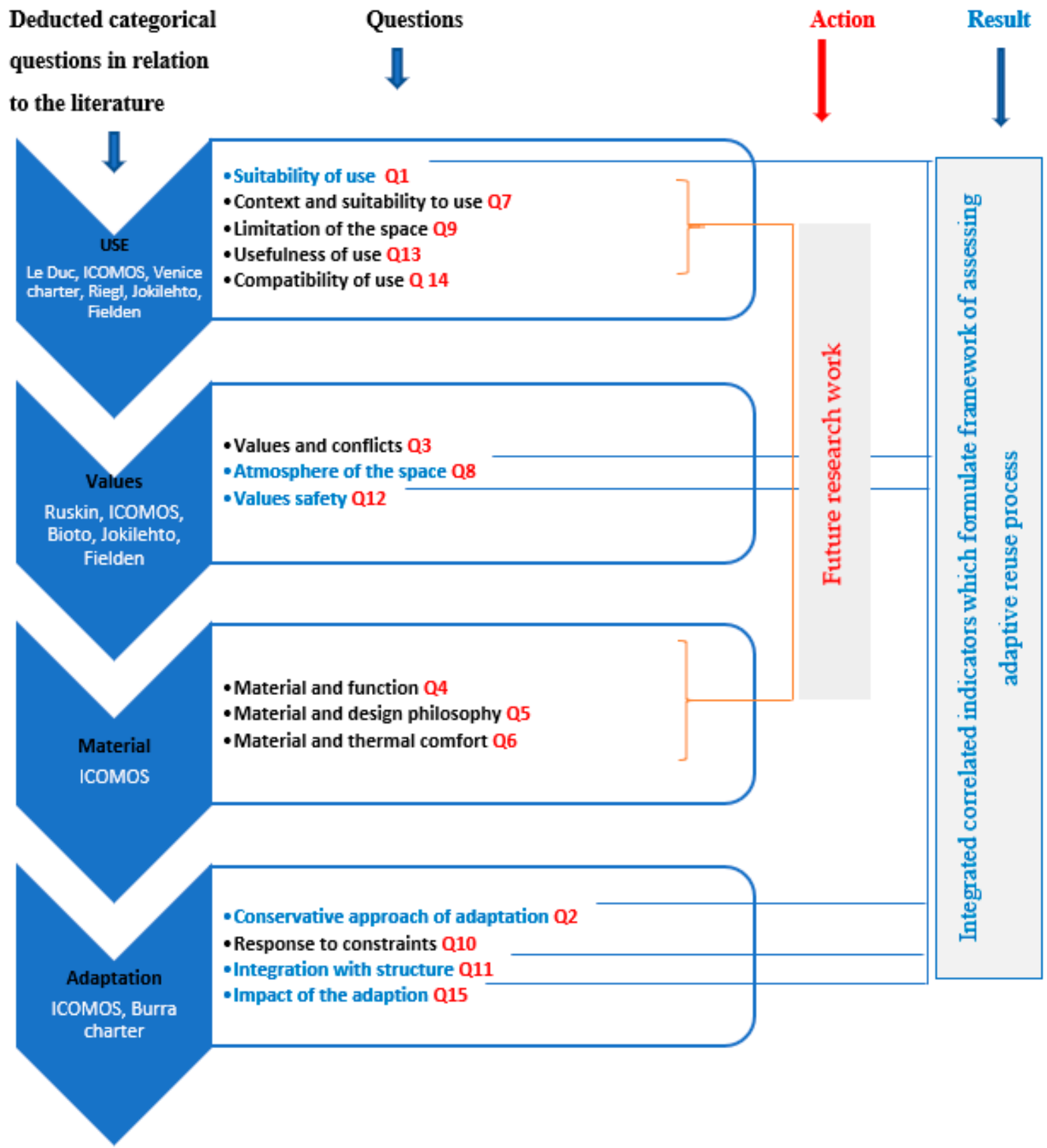

Figure 11. Analysis result in relation to literature and questions. 
Table 6. Strong correlation figures are shown in blue; significance figures are highlighted in red.

\begin{tabular}{|c|c|c|c|c|c|c|c|c|c|c|c|c|c|c|c|c|}
\hline \multicolumn{17}{|c|}{ Correlations 1-Tailed } \\
\hline & & $\begin{array}{l}\text { Is the } \\
\text { Build- } \\
\text { ing } \\
\text { Pre- } \\
\text { pared } \\
\text { to Suit } \\
\text { the } \\
\text { Use as } \\
\text { NOUH }\end{array}$ & $\begin{array}{l}\text { 10. Is } \\
\text { the Ap- } \\
\text { proach } \\
\text { of } \\
\text { Adapt- } \\
\text { ing the } \\
\text { Build- } \\
\text { ing to } \\
\text { Reuse } \\
\text { Con- } \\
\text { serva- } \\
\text { tive }\end{array}$ & $\begin{array}{c}\text { Does } \\
\text { the } \\
\text { Adap- } \\
\text { tation } \\
\text { Have } \\
\text { Any } \\
\text { Con- } \\
\text { flict } \\
\text { with } \\
\text { Values } \\
\text { of Ar- } \\
\text { chitec- } \\
\text { tural, } \\
\text { His- } \\
\text { toric } \\
\text { and so } \\
\text { on }\end{array}$ & $\begin{array}{l}\text { Do } \\
\text { you } \\
\text { Think } \\
\text { That } \\
\text { the } \\
\text { Build- } \\
\text { ing's } \\
\text { Materi- } \\
\text { als Are } \\
\text { De- } \\
\text { signed } \\
\text { to } \\
\text { Achieve } \\
\text { Func- } \\
\text { tion }\end{array}$ & $\begin{array}{c}\text { Do } \\
\text { you } \\
\text { Think } \\
\text { That } \\
\text { the } \\
\text { Build- } \\
\text { ing's } \\
\text { Materi- } \\
\text { als Are } \\
\text { De- } \\
\text { signed } \\
\text { to } \\
\text { Achieve } \\
\text { Design } \\
\text { Philos- } \\
\text { ophy }\end{array}$ & $\begin{array}{c}\text { Do } \\
\text { you } \\
\text { Think } \\
\text { That } \\
\text { the } \\
\text { Build- } \\
\text { ing's } \\
\text { Materi- } \\
\text { als Are } \\
\text { De- } \\
\text { signed } \\
\text { to } \\
\text { Achieve } \\
\text { Ther- } \\
\text { mal } \\
\text { Com- } \\
\text { fort }\end{array}$ & $\begin{array}{l}\text { Does } \\
\text { the } \\
\text { His- } \\
\text { toric } \\
\text { Setting } \\
\text { of the } \\
\text { Citadel } \\
\text { Suit } \\
\text { the } \\
\text { NOUH } \\
\text { Func- } \\
\text { tion } \\
\text { and } \\
\text { Work } \\
\text { Re- } \\
\text { quire- } \\
\text { ment }\end{array}$ & $\begin{array}{c}\text { Do } \\
\text { you } \\
\text { Value } \\
\text { That } \\
\text { Your } \\
\text { Work } \\
\text { Is at } \\
\text { His- } \\
\text { toric } \\
\text { Build- } \\
\text { ings }\end{array}$ & $\begin{array}{c}\text { Being } \\
\text { at a } \\
\text { His- } \\
\text { toric } \\
\text { Build- } \\
\text { ing, } \\
\text { Do } \\
\text { You } \\
\text { Think } \\
\text { That } \\
\text { You } \\
\text { Have } \\
\text { Limita- } \\
\text { tion in } \\
\text { Work, } \\
\text { Trans- } \\
\text { porta- } \\
\text { tion, } \\
\text { and so } \\
\text { on }\end{array}$ & 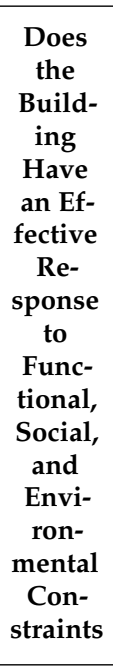 & $\begin{array}{l}\text { Does } \\
\text { the } \\
\text { Use of } \\
\text { the } \\
\text { Build- } \\
\text { ing as } \\
\text { NOUH } \\
\text { Re- } \\
\text { spect } \\
\text { the In- } \\
\text { tegrity } \\
\text { of the } \\
\text { Struc- } \\
\text { ture, } \\
\text { Its } \\
\text { Char- } \\
\text { acter }\end{array}$ & $\begin{array}{l}\text { Are } \\
\text { the } \\
\text { Build- } \\
\text { ing's } \\
\text { Safety } \\
\text { Condi- } \\
\text { tions } \\
\text { Taken } \\
\text { into } \\
\text { Ac- } \\
\text { count }\end{array}$ & $\begin{array}{l}\text { Is the } \\
\text { Use } \\
\text { Useful }\end{array}$ & $\begin{array}{l}\text { Does } \\
\text { the } \\
\text { Build- } \\
\text { ing } \\
\text { Has a } \\
\text { Com- } \\
\text { patible } \\
\text { Use }\end{array}$ & 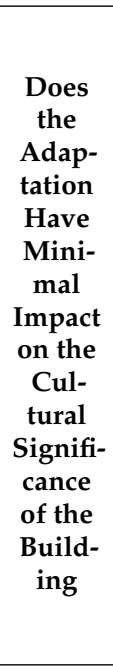 \\
\hline $\begin{array}{l}\text { Is the building prepared to suit the } \\
\text { use as NOUH }\end{array}$ & $\begin{array}{l}\text { Pearson } \\
\text { Correlation }\end{array}$ & 1 & 0.775 & -0.166 & 0.51 & 0.286 & -0.056 & -0.151 & 0.781 & -0.212 & -0.101 & 0.51 & 0.386 & 0.266 & 0.351 & 0.5 \\
\hline \multirow{2}{*}{$\begin{array}{l}\text { Is the approach of adapting the } \\
\text { building to reuse conservative }\end{array}$} & $\begin{array}{l}\text { Pearson } \\
\text { Correlation }\end{array}$ & 0.775 & 1 & -0.230 & 0.152 & 0.506 & 0.140 & 0.209 & 0.822 & -0.539 & -0.009 & 0.390 & 0.683 & 0.181 & 0.199 & 0.464 \\
\hline & Sig. (1-tailed) & 0.001 & & 0.215 & 0.301 & 0.032 & 0.317 & 0.236 & 0.000 & 0.023 & 0.487 & 0.084 & 0.004 & 0.268 & 0.247 & 0.047 \\
\hline \multirow{4}{*}{$\begin{array}{l}\text { Does the adaptation have any } \\
\text { conflict with values of } \\
\text { architectural, historic, and so on } \\
\text { Do you think that the building's } \\
\text { materials are designed to achieve } \\
\text { function }\end{array}$} & $\begin{array}{l}\text { Pearson } \\
\text { Correlation }\end{array}$ & -0.166 & -0.230 & 1 & -0.218 & -0.406 & -0.092 & -0.083 & -0.031 & 0.113 & -0.554 & 0.251 & -0.106 & 0.159 & -0.061 & 0.032 \\
\hline & Sig. (1-tailed) & 0.285 & 0.215 & & 0.227 & 0.075 & 0.377 & 0.389 & 0.458 & 0.350 & 0.020 & 0.193 & 0.360 & 0.294 & 0.418 & 0.457 \\
\hline & $\begin{array}{l}\text { Pearson } \\
\text { Correlation }\end{array}$ & 0.51 & 0.152 & -0.218 & 1 & 0.415 & -0.082 & -0.366 & 0.190 & -0.031 & 0.224 & 0.352 & 0.070 & -0.146 & 0.369 & 0.053 \\
\hline & Sig. (1-tailed) & 0.031 & 0.301 & 0.227 & & 0.070 & 0.391 & 0.099 & 0.258 & 0.458 & 0.220 & 0.109 & 0.406 & 0.309 & 0.097 & 0.428 \\
\hline \multirow{6}{*}{$\begin{array}{l}\text { Do you think that the building's } \\
\text { materials are designed to achieve } \\
\text { design philosophy } \\
\text { Do you think that the building's } \\
\text { materials are designed to achieve } \\
\text { thermal comfort } \\
\text { Does the historic setting of the } \\
\text { citadel suits= the NOUH function } \\
\text { and work requirement }\end{array}$} & $\begin{array}{l}\text { Pearson } \\
\text { Correlation }\end{array}$ & 0.286 & 0.506 & -0.406 & 0.415 & 1 & 0.514 & -0.085 & 0.355 & -0.331 & 0.419 & -0.069 & 0.283 & 0.014 & -0.188 & 0.100 \\
\hline & Sig. (1-tailed) & 0.161 & 0.032 & 0.075 & 0.070 & & 0.030 & 0.386 & 0.107 & 0.124 & 0.068 & 0.407 & 0.163 & 0.482 & 0.260 & 0.367 \\
\hline & $\begin{array}{l}\text { Pearson } \\
\text { Correlation }\end{array}$ & -0.056 & 0.140 & -0.092 & -0.082 & 0.514 & 1 & 0.050 & 0.152 & -0.189 & 0.258 & -0.224 & -0.026 & -0.153 & -0.351 & -0.363 \\
\hline & Sig. (1-tailed) & 0.424 & 0.317 & 0.377 & 0.391 & 0.030 & & 0.432 & 0.302 & 0.258 & 0.186 & 0.220 & .465 & 0.301 & 0.110 & 0.101 \\
\hline & $\begin{array}{l}\text { Pearson } \\
\text { Correlation }\end{array}$ & -0.151 & 0.209 & -0.083 & -0.366 & -0.085 & 0.050 & 1 & -0.085 & -0.335 & 0.252 & 0.183 & 0.461 & -0.181 & 0.248 & -0.132 \\
\hline & Sig. (1-tailed) & 0.303 & 0.236 & 0.389 & 0.099 & 0.386 & 0.432 & & 0.386 & 0.121 & 0.193 & 0.266 & 0.049 & 0.268 & 0.196 & 0.327 \\
\hline
\end{tabular}


Table 6. Cont.

Correlations 1-Tailed

\begin{tabular}{|c|c|c|c|c|c|c|c|c|c|c|c|c|c|c|c|c|}
\hline \multicolumn{17}{|c|}{ Correlations 1-Tailed } \\
\hline & & $\begin{array}{l}\text { Is the } \\
\text { Build- } \\
\text { ing } \\
\text { Pre- } \\
\text { pared } \\
\text { to Suit } \\
\text { the } \\
\text { Use as } \\
\text { NOUH }\end{array}$ & $\begin{array}{l}\text { 10. Is } \\
\text { the Ap- } \\
\text { proach } \\
\text { of } \\
\text { Adapt- } \\
\text { ing the } \\
\text { Build- } \\
\text { ing to } \\
\text { Reuse } \\
\text { Con- } \\
\text { serva- } \\
\text { tive }\end{array}$ & $\begin{array}{c}\text { Does } \\
\text { the } \\
\text { Adap- } \\
\text { tation } \\
\text { Have } \\
\text { Any } \\
\text { Con- } \\
\text { flict } \\
\text { with } \\
\text { Values } \\
\text { of Ar- } \\
\text { chitec- } \\
\text { tural, } \\
\text { His- } \\
\text { toric } \\
\text { and so } \\
\text { on }\end{array}$ & $\begin{array}{l}\text { Do } \\
\text { you } \\
\text { Think } \\
\text { That } \\
\text { the } \\
\text { Build- } \\
\text { ing's } \\
\text { Materi- } \\
\text { als Are } \\
\text { De- } \\
\text { signed } \\
\text { to } \\
\text { Achieve } \\
\text { Func- } \\
\text { tion }\end{array}$ & $\begin{array}{c}\text { Do } \\
\text { you } \\
\text { Think } \\
\text { That } \\
\text { the } \\
\text { Build- } \\
\text { ing's } \\
\text { Materi- } \\
\text { als Are } \\
\text { De- } \\
\text { signed } \\
\text { to } \\
\text { Achieve } \\
\text { Design } \\
\text { Philos- } \\
\text { ophy }\end{array}$ & $\begin{array}{c}\text { Do } \\
\text { you } \\
\text { Think } \\
\text { That } \\
\text { the } \\
\text { Build- } \\
\text { ing's } \\
\text { Materi- } \\
\text { als Are } \\
\text { De- } \\
\text { signed } \\
\text { to } \\
\text { Achieve } \\
\text { Ther- } \\
\text { mal } \\
\text { Com- } \\
\text { fort }\end{array}$ & $\begin{array}{c}\text { Does } \\
\text { the } \\
\text { His- } \\
\text { toric } \\
\text { Setting } \\
\text { of the } \\
\text { Citadel } \\
\text { Suit } \\
\text { the } \\
\text { NOUH } \\
\text { Func- } \\
\text { tion } \\
\text { and } \\
\text { Work } \\
\text { Re- } \\
\text { quire- } \\
\text { ment }\end{array}$ & $\begin{array}{c}\text { Do } \\
\text { you } \\
\text { Value } \\
\text { That } \\
\text { Your } \\
\text { Work } \\
\text { Is at } \\
\text { His- } \\
\text { toric } \\
\text { Build- } \\
\text { ings }\end{array}$ & $\begin{array}{c}\text { Being } \\
\text { at a } \\
\text { His- } \\
\text { toric } \\
\text { Build- } \\
\text { ing, } \\
\text { Do } \\
\text { You } \\
\text { Think } \\
\text { That } \\
\text { You } \\
\text { Have } \\
\text { Limita- } \\
\text { tion in } \\
\text { Work, } \\
\text { Trans- } \\
\text { porta- } \\
\text { tion, } \\
\text { and so } \\
\text { on }\end{array}$ & $\begin{array}{c}\text { Does } \\
\text { the } \\
\text { Build- } \\
\text { ing } \\
\text { Have } \\
\text { an Ef- } \\
\text { fective } \\
\text { Re- } \\
\text { sponse } \\
\text { to } \\
\text { Func- } \\
\text { tional, } \\
\text { Social, } \\
\text { and } \\
\text { Envi- } \\
\text { ron- } \\
\text { mental } \\
\text { Con- } \\
\text { straints }\end{array}$ & $\begin{array}{l}\text { Does } \\
\text { the } \\
\text { Use of } \\
\text { the } \\
\text { Build- } \\
\text { ing as } \\
\text { NOUH } \\
\text { Re- } \\
\text { spect } \\
\text { the In- } \\
\text { tegrity } \\
\text { of the } \\
\text { Struc- } \\
\text { ture, } \\
\text { Its } \\
\text { Char- } \\
\text { acter }\end{array}$ & $\begin{array}{l}\text { Are } \\
\text { the } \\
\text { Build- } \\
\text { ing's } \\
\text { Safety } \\
\text { Condi- } \\
\text { tions } \\
\text { Taken } \\
\text { into } \\
\text { Ac- } \\
\text { count }\end{array}$ & $\begin{array}{l}\text { Is the } \\
\text { Use } \\
\text { Useful }\end{array}$ & $\begin{array}{c}\text { Does } \\
\text { the } \\
\text { Build- } \\
\text { ing } \\
\text { Has a } \\
\text { Com- } \\
\text { patible } \\
\text { Use }\end{array}$ & $\begin{array}{c}\text { Does } \\
\text { the } \\
\text { Adap- } \\
\text { tation } \\
\text { Have } \\
\text { Mini- } \\
\text { mal } \\
\text { Impact } \\
\text { on the } \\
\text { Cul- } \\
\text { tural } \\
\text { Signifi- } \\
\text { cance } \\
\text { of the } \\
\text { Build- } \\
\text { ing }\end{array}$ \\
\hline $\begin{array}{l}\text { Do you value that your work is at } \\
\text { a historic building }\end{array}$ & $\begin{array}{l}\text { Pearson } \\
\text { Correlation }\end{array}$ & 0.781 & 0.822 & -0.031 & 0.190 & 0.355 & 0.152 & -0.085 & 1 & -0.078 & -0.019 & 0.553 & 0.632 & 0.464 & 0.406 & 0.598 \\
\hline \multirow{6}{*}{$\begin{array}{l}\text { Being at a historic building, do } \\
\text { you think that you have limitation } \\
\text { in work, transportation, and so on } \\
\text { Does the building has an effective } \\
\text { response to functional, social, and } \\
\text { environmental constraints } \\
\text { Does the use of the building as } \\
\text { NOUH respect the integrity of the } \\
\text { structure, its character }\end{array}$} & $\begin{array}{l}\text { Pearson } \\
\text { Correlation }\end{array}$ & -0.212 & -0.539 & 0.113 & -0.031 & -0.331 & -0.189 & -0.335 & -0.078 & 1 & 0.270 & 0.188 & -0.171 & 0.597 & 0.311 & 0.325 \\
\hline & Sig. (1-tailed) & 0.233 & 0.023 & 0.350 & 0.458 & 0.124 & 0.258 & 0.121 & 0.396 & & 0.175 & 0.260 & 0.280 & 0.012 & 0.139 & 0.128 \\
\hline & $\begin{array}{l}\text { Pearson } \\
\text { Correlation }\end{array}$ & -0.101 & -0.009 & -0.554 & 0.224 & 0.419 & 0.258 & 0.252 & -0.019 & 0.270 & 1 & 0.224 & 0.386 & 0.040 & 0.351 & 0.088 \\
\hline & Sig. (1-tailed) & 0.365 & 0.487 & 0.020 & 0.220 & 0.068 & 0.186 & 0.193 & 0.474 & 0.175 & & 0.220 & 0.087 & 0.446 & 0.110 & 0.382 \\
\hline & $\begin{array}{l}\text { Pearson } \\
\text { Correlation }\end{array}$ & 0.51 & 0.390 & 0.251 & 0.352 & -0.069 & -0.224 & 0.183 & 0.553 & 0.188 & 0.224 & 1 & 0.723 & 0.366 & 0.838 & 0.552 \\
\hline & Sig. (1-tailed) & 0.031 & 0.084 & 0.193 & 0.109 & 0.407 & 0.220 & 0.266 & 0.020 & 0.260 & 0.220 & & 0.002 & 0.099 & 0.000 & 0.020 \\
\hline \multirow{2}{*}{$\begin{array}{l}\text { Are the building's safety } \\
\text { conditions taken into account }\end{array}$} & $\begin{array}{l}\text { Pearson } \\
\text { Correlation }\end{array}$ & 0.386 & 0.683 & -0.106 & 0.070 & 0.283 & -0.026 & 0.461 & 0.632 & -0.171 & 0.386 & 0.723 & 1 & 0.277 & 0.633 & 0.448 \\
\hline & Sig. (1-tailed) & 0.087 & 0.004 & 0.360 & 0.406 & 0.163 & 0.465 & 0.049 & 0.008 & 0.280 & 0.087 & 0.002 & & 0.169 & 0.008 & 0.054 \\
\hline \multirow[t]{2}{*}{ Is the use useful } & $\begin{array}{l}\text { Pearson } \\
\text { Correlation }\end{array}$ & 0.266 & 0.181 & 0.159 & -0.146 & 0.014 & -0.153 & -0.181 & 0.464 & 0.597 & 0.040 & 0.366 & 0.277 & 1 & 0.251 & 0.752 \\
\hline & Sig. (1-tailed) & 0.179 & 0.268 & 0.294 & 0.309 & 0.482 & 0.301 & 0.268 & 0.047 & 0.012 & 0.446 & 0.099 & 0.169 & & 0.193 & 0.001 \\
\hline \multirow{2}{*}{$\begin{array}{l}\text { Does the building has a } \\
\text { compatible use }\end{array}$} & $\begin{array}{l}\text { Pearson } \\
\text { Correlation }\end{array}$ & 0.351 & 0.199 & -0.061 & 0.369 & -0.188 & -0.351 & 0.248 & 0.406 & 0.311 & 0.351 & 0.838 & 0.633 & 0.251 & 1 & 0.370 \\
\hline & Sig. (1-tailed) & 0.110 & 0.247 & 0.418 & 0.097 & 0.260 & 0.110 & 0.196 & 0.075 & 0.139 & 0.110 & 0.000 & 0.008 & 0.193 & & 0.096 \\
\hline \multirow{2}{*}{$\begin{array}{l}\text { Is the Adaptation has minimal } \\
\text { impact on the cultural significance } \\
\text { of the building }\end{array}$} & $\begin{array}{c}\text { Pearson } \\
\text { Correlation }\end{array}$ & 0.5 & 0.464 & 0.032 & 0.053 & 0.100 & -0.363 & -0.132 & 0.598 & 0.325 & 0.088 & 0.552 & 0.448 & 0.752 & 0.370 & 1 \\
\hline & Sig. (1-tailed) & 0.034 & 0.047 & 0.457 & 0.428 & 0.367 & 0.101 & 0.327 & 0.012 & 0.128 & 0.382 & 0.020 & 0.054 & 0.001 & 0.096 & \\
\hline
\end{tabular}


A statistical analysis was performed to study both crosstab descriptive analysis, which shows the positive indicators of the suitability of adaptive reuse, as well as chi-square and symmetry measures. Both suggest associations and correlations, which drove us to perform the advanced predictive correlation test. The correlation analysis was carried out to assess the adaptive reuse variables. These variables came from the literature review study.

The correlation test shows the factors of association and the significance of the correlation, but some of the variables were associated, so that it is recommended that they be used together if this methodology is adapted for a similar case, as this set suggested an association and a strong correlation. However, if used separately, these adaptive reuse variables may not be achieved perfectly.

The adaptive reuse questionnaire, which consisted of 15 questions, ended with a shortlist of 6 questions representing the adaptive reuse status variables. As mentioned previously, the indicators extracted from the ICOMOS charters have a high correlation with six questions: Is the building prepared to suit the NOUH? Is the approach of adapting the building for reuse conservative? Do you value working in a historic building? Does the use of the building by the NOUH respect the integrity of the structure and its character? Are the building's safety conditions taken into account? Does the adaptation have a minimal impact on the cultural significance of the building?

The building's preparation to suit the use of one of three associated indicators, alongside five other indicators (according to Figure 11), correlated with questions or indicators from $-2,4,8,11$, and 15, which shows the importance of these indicators. On the other hand, two other indicators, those that referred to working in a historic building, were found to be highly correlated with questions or indicators from $1,2,11,12$, and 15 . The use of the building with respect to its integrity, structure, and character correlated with 1,8,12,14 and 15 , the second set, which contains another three indicators. Every indicator associated with the other four branches, which are conserved within the adaptive approach, correlated with 1, 5, 8 and 12. The building value safety condition was considered and correlated with 2, 8, 11 and 14. The impact of the building's adaptation on the cultural significance correlated with indicators numbers $1,8,11$ and 13. A secondary correlation was also found with six other indicators that were not associated with questions 4, 5, 14 and 13.

The holistic approach explored in this research in relation to adaptive reuse will likely be useful in implementing the six indicators as a basic framework that should be considered when adapting various aspects of historic buildings for new uses. The correlation coefficient is strong when considering the six indicators as a whole.

Crosstab, as a first step analysis, shows the preliminary directions of the answers in addition to association-correlated indicators, and because it has a positive direction of approving most of the indicators which are already embedded at the questions, the result from the crosstab reveals that these correlation lead to the performance of the second level of analysis, which is the correlation coefficient to show associations and significances between which indicators exactly are to be considered together while implementing an adaptive reuse plan.

From the results, it is obvious that the material category and relation of use to context need more future research to discover its impact and contribution to the adaptive reuse process, from the function, and its reflection and suitability to the philosophy of adaptive reuse purpose and its role in thermal comfort assessment (Figure 11)

In addition, the suitability of use is appreciated on the heritage building level, not on the contextual level or on the compatibility and usefulness level. This means the minimum level of suitability satisfy the users because of its uniqueness.

\section{Conclusions and Future Developments}

This research highlighted how incorrect adaptive reuse decisions could lead to the wrong approach-implementing a rigid adaptive reuse model without taking the necessary measures caused much more energy consumption than was necessary. 
The simulation results confirmed the minimal need for cooling loads during summer, with more heating loads during winter. There are some discrepancies between the subjective/objective assessments. Nevertheless, both reported that occupants' thermal sensation is between slightly warm to warm in summer and somewhat cool to cool in winter. Avoiding the feeling of being hot in Cairo during the hottest month is considered an excellent achievement in regard to building properties. The authors of this research believe that such a building, with its conditions and construction materials, requires an active heating system to allow occupants to work effectively. At the same time, natural ventilation and passive cooling techniques can adjust the air temperature to lie inside the comfort zone for the rest of the year and during the summer season via the use of light mechanical tools such as fans.

The statistical analysis formulated the two levels of research; the first crosstab description reveals an association between the adaptive reuse variables, which were extracted from the international charters by ICOMOS. This association led to the second level of analysis, which was the predictive correlation coefficient test, which had been used previously in order to define the significant indicators that control and enhance the suitability of the adaptive reuse approach. The correlations showed strength in six indicators and formulated a basic frame for the adaptation of various aspects of historic buildings.

Full consideration of a building's energy consumption can be made when applying the necessary measures to suitably adapted buildings. Egypt has many historic listed buildings. Making the correct decisions can maintain both the conservation of historic buildings and their reuse requirements in regard to thermal comfort and energy consumption, with a particular focus on adaptive reuse.

Simulation and statistical methods assessed the adaptive reuse decisions. This allowed for the determination of the major factors regarding the adaptive reuse indicators and thermal comfort needs that can enhance a historic building's performance, as it was demonstrated in the case study of the administrative head office of the National Organization of Urban Harmony. The administration has similar facilities, and the findings for this category of building, composed of similar common materials and with a similar structure, which is commonly found globally, may also be applicable to these facilities. Based on its unique location, upon the highest point in Cairo, the Citadel of the mountain, with all its historical layers corresponding to various historically Islamic eras, tells a thousand stories and remains useful, even today, representing the unique combination of the past, present, and future.

The futuristic vision of heritage conservation outlined clearly in Salvador Muñoz Viñas, as he stated that "Classical conservation theories (from Ruskin to Brandi) are characterized by their close adherence to Truth. These theories are currently dominant, but criticism and new alternatives are developing and gaining momentum. Three crucial notions in classical theories have been criticized: reversibility, universality and objectivity (including objective determination of damage and the notion of scientific conservation). As a result of these criticisms, emerging contemporary theory of conservation has substituted the notion of function, use or value of the conservation object for that of Truth, in the 'negotiation' that modern conservation theory calls for, future users have to play a role, and, most likely, it will be the experts who will have to speak for them" [39].

A new era of adaptive reuse has to start with addressing the sustainable adaptive reuse, which has to contribute to innovation economy, environmental sustainability, and social inclusion, in addition to culture and identity. Many steps defined by the European Union in the publication guidelines for sustainable adaptive reuse, such as an analysis of the cases, which were focused on in this research, then designing the vision of the adaptive reuse in addition to breaking it into objectives, identifying stakeholder, changes appearing due to the adaptation, and the long-term plan of conservation and operation to be added [42].

As mentioned previously, a multiple approach of adaptive reuse can be used according to Francesco Leccese et al., 2021, can include air quality, acoustics, and lighting, which 
will be considered in future research to examine the impact of those additional factors on the adaptive reuse process and the users as well [43]. POE also focused on this research on the behavioral and personal, while multi-perceptional and behavioral factors might be used as physical, contextual, personal, and others according to Marcel Schweiker et. $\mathrm{Al}, 2020$. Yhis can be achieved through multiple case studies in different conditions in terms of context, user behaviors, typologies of the buildings, and use [44] as this field still misses deep scientific comparisons considering the different uniqueness of every historic building due to the cultural diversity to enrich the decisions for the adaptive reuse of historic buildings [45].

Author Contributions: The Conceptualization and preliminary idea done by Y.S.H., H.A.S. and M.A.A.M.; in addition to the methodology, software, done by M.A.A.M.; validation, Y.S.H., H.A.S. and M.A.A.M.; formal statistical analysis, Y.S.H.; investigation, H.A.S.; resources, Y.S.H., H.A.S. and M.A.A.M.; data curation, Y.S.H., H.A.S. and M.A.A.M.; writing-original draft preparation, Y.S.H., H.A.S. and M.A.A.M.; writing-review and editing, MDPI language editing services; visualization, Y.S.H., H.A.S.; supervision, by All author; project administration, by All authors; funding acquisition, by All authors. All authors have read and agreed to the published version of the manuscript.

Funding: This research received no external funding.

Institutional Review Board Statement: Not applicable.

Informed Consent Statement: Informed consent was obtained from all subjects involved in the study.

Data Availability Statement: Any data analysis files are available to be presented upon request, from simulation files, SPSS analysis files and so on.

Conflicts of Interest: Authors declare that no conflict of interest at this research.

\section{References}

1. Tu, H.-M. The attractiveness of adaptive heritage reuse: A theoretical framework. Sustainability 2020, 12, 2372. [CrossRef]

2. Ganobjak, M.; Brunner, S.; Wernery, J. Aerogel Materials for Heritage Buildings: Materials, Properties and Case Studies. J. Cult. Herit. 2020, 42, 81-98. [CrossRef]

3. Macdonald, S.L.; Cheong, C. The Role of Public-Private Partnerships and the Third Sector in Conserving Heritage Buildings, Sites, and Historic Urban Areas; The Getty Conservation Institute: Los Angeles, CA, USA, 2014.

4. Nesticò, A.; Morano, P.; Sica, F. A model to support the public administration decisions for the investments selection on historic buildings. J. Cult. Herit. 2017, 33, 201-207. [CrossRef]

5. Ministry of Culture. The Supreme Council of Antiquities; Law no. 117 of 1983; UNESCO: Cairo, Egypt, 2010; Volume 117, pp. 1-40.

6. Wright, K.R.; Wright, R.; Zegarra, A.V.; McEwan, G. (Eds.) Construction engineering. In Moray; American Society of Civil Engineers: Dulles, VA, USA, 2011; pp. 56-85.

7. Fabbri, K. Energy incidence of historic building: Leaving no stone unturned. J. Cult. Herit. 2013, 14S, e25-e27. [CrossRef]

8. Islami, S.G.; Dehghan, D.; Naeini, H.S. A model development to adaptive reuse of Iranian Qajar houses: An approach to sociocultural concept (A case: Nasir Al-Din Mirza house). Am. J. Civ. Eng. Archit. 2016, 4, 84-89. [CrossRef]

9. Jokilehto, J. A History of Architectural Conservation. Ph.D. Thesis, The University of York, York, UK, September 1986.

10. Ruskin, J. The seven lamps of architecture. Bull. Am. Art-Union 1849, 2, 11-21. [CrossRef]

11. Petzet, M.; Ziesemer, J. International Charters for Conservation and Restoration, Fédération, R. De. Icomos 49-51, 0, 0-53. Available online: http:/ / openarchive.icomos.org/id/eprint/431/ (accessed on 20 June 2021).

12. ICOMOS. International Charter for The Conservation and Restoration of Monuments and Sites (The Venice Charter 1964); ICOMOS: Paris, France, 1964.

13. ICOMOS. Vernacular Architecture Charter; ICOMOS: Paris, France, 1999.

14. Truscott, M.C. Burra Charter: The Australia ICOMOS Charter for Places of Cultural Significance (1999); ICOMOS: Paris, France, 2014; pp. 1078-1082.

15. Webb, A. Energy retrofits in historic and traditional buildings: A review of problems and methods. J. Cult. Herit. 2017, 77, 748-759. [CrossRef]

16. Zeayter, H.; Mansour, A.M.H. Heritage conservation ideologies analysis-Historic urban Landscape approach for a Mediterranean historic city case study. HBRC J. 2017, 14, 345-356. [CrossRef]

17. Dell'Ovo, M.; Dell'Anna, F.; Simonelli, R.; Sdino, L. Enhancing the Cultural Heritage through Adaptive Reuse. A Multicriteria Approach to Evaluate the Castello Visconteo in Cusago (Italy). Sustainability 2021, 13, 4440. [CrossRef]

18. Gado, T.; Mohamed, M.; Osman, M. Investigating the intelligence of the low-tech earth architecture of the Sahara: A feasibility study from the western desert of Egypt. Intell. Build. Int. 2010, 2, 179-197. [CrossRef] 
19. Langston, C.A. Green adaptive reuse: Issues and strategies for the built environment. In Modeling Risk Management in Sustainable Construction; Wu, D.D., Ed.; Springer: Berlin/Heidelberg, Germany, 2010; pp. 199-209.

20. Hartman, V.; Kirac, M.; Zanki, V.; Grozdek, M.; Poletto, D.; Ronchini, C. Energy Efficiency and Energy Management in Cultural Heritage; United Nations Development Programme in Croatia: Zagreb, Croatia, 2013; ISBN 978-953-7429-47-8.

21. De Santoli, L. Guidelines on energy efficiency of cultural heritage. Energy Build. 2015, 86, 534-540. [CrossRef]

22. Troi, A.; Bastian, Z. Energy Efficiency Solutions for Historic Buildings: A Handbook; Birkhäuser: Berlin, Germany; München, Germany; Boston, MA, USA, 2014; Available online: https:/ / doi.org/10.1515/9783038216506 (accessed on 31 May 2020).

23. De Rubeis, T.; Nardi, I.; Muttillo, M.; Paoletti, D. The restoration of severely damaged churches-Implications and opportunities on cultural heritage conservation, thermal comfort and energy efficiency. J. Cult. Herit. 2020, 43, 186-203. [CrossRef]

24. Şahin, C.D.; Arsan, Z.D.; Tunçoku, S.S.; Broström, T.; Akkurt, G.G. A transdisciplinary approach on the energy efficient retrofitting of a historic building in the Aegean Region of Turkey. Energy Build. 2015, 96, 128-139. [CrossRef]

25. Magrini, A.; Franco, G. The energy performance improvement of historic buildings and their environ-mental sustainability assessment. J. Cult. Herit. 2016, 21, 834-841. [CrossRef]

26. Galatioto, A.; Ciulla, G.; Ricciu, R. An overview of energy retrofit actions feasibility on Italian historical buildings. Energy 2017, 137, 991-1000. [CrossRef]

27. Balocco, C.; Petrone, G.; Maggi, O.; Pasquariello, G.; Albertini, R.; Pasquarella, C. Indoor microclimatic study for Cultural Heritage protection and preventive conservation in the Palatina Library. J. Cult. Herit. 2016, 22, 956-967. [CrossRef]

28. Martins, A.M.; Carlos, J.S. The retrofitting of the Bernardas' Convent in Lisbon. Energy Build. 2014, 68, 396-402. [CrossRef]

29. Khalil, A.M.R.; Hammouda, N.Y.; El-Deeb, K.F. Implementing sustainability in retrofitting heritage buildings. Case study: Villa Antoniadis, Alexandria, Egypt. Heritage 2018, 1, 57-87. [CrossRef]

30. Wikipedia, Shubra Palace. Available online: https:/ / en.wikipedia.org/wiki/Shubra_Palace (accessed on 9 September 2021).

31. Ministry of Municipal and Rural Affairs and United Nations Human Settlements Program. Taif City Profile; Future Saudi Cities Program Series; UN-Habitat: Riyadh, Saudi Arabia, 2019; ISBN 978-603-8279-22-9.

32. Mamdooh, A.; Ashraf, B.; Ahmed, A.; Usama, I.; Ibrahim, S.; Amal, S.; Mohammed, A.-S.; Mosleh, A.-H.; Mohamed, G. User Thermal Comfort in Historic Buildings: Evaluation of the Potential of Thermal Mass, Orientation, Evaporative Cooling and Ventilation. Sustainability 2020, 12, 9672. [CrossRef]

33. Wafy, Shubra Palace: A Historic Cornerstone of Taif. Available online: https://www.wafyapp.com/en/article/shubra-palace-ahistoric-cornerstone-of-taif (accessed on 31 May 2020).

34. Description-International Food Fair. Available online: https:/ /www.bibalex.org/food/venue.html (accessed on 9 September 2021).

35. Şahin, C.D. Energy Efficient Retrofitting of Historical Buildings: A Case Study on The Building of Basmane Semt Merkezi-İzmir. Ph.D. Dissertation, The Graduate School of Engineering and Sciences of İzmir Institute of Technology, İzmir, Turkey, 2013.

36. Muñoz-González, C.M.; León-Rodríguez, A.L.; Campano-Laborda, M.; Teeling, C.; Baglioni, R. The assessment of environmental conditioning techniques and theirenergy performance in historic churches located in Mediterranean climate. J. Cult. Herit. 2017, 34, 74-82. [CrossRef]

37. INNOVA. Thermal Comfort, AirTech Instruments; INNOVA: Seoul, Korea, 2004.

38. HSE. Thermal Comfort. Available online: http://www.hse.gov.uk/temperature/thermal/index.htm (accessed on 20 June 2006).

39. ASHRAE. ASHRAE 2005 Fundamentals Handbook; ASHRAE: Atlanta, GA, USA, 2005.

40. Hamdy, M. North Eastern of the Citadel from Aybbid till Othoman. Ph.D. Thesis, Faculty of Antiquities, Cairo University, Cairo, Egypt, 2001.

41. National Organization for Urban Harmony. 2010. Available online: www.urbanharmony.org (accessed on 6 November 2020).

42. CIBSE. CIBSE Guide A: Environmental Design; Yale Press Ltd.: London, UK, 1999.

43. Leccese, F.; Rocca, M.; Salvadori, G.; Belloni, E.; Buratti, C. Towards a holistic approach to indoor environmental quality assessment: Weighting schemes to combine effects of multiple environmental factors. Energy Build. 2021, 245, 111056. [CrossRef]

44. Marcel, S.; Eleni, A.; Maedot, S.A.; Rune, K.A.; Elie, A.; Verena, M.B.; Christiane, B.; Leonidas, B.; Salvatore, C.; Giorgia, C.; et al. Review of multi-domain approaches to indoor environmental perception and behaviour. Energy Build. 2020, 176, 106804. [CrossRef]

45. Mohamed, M. An approach to integrate the environmental impact assessment process in the early stages of design. In The First International Engineering Conference Hosting Major International Events Innovation, Creativity and Impact Assessment; Housing \& Building National Research Center: Cairo, Egypt, 2013. 